University of Wollongong

Research Online

Faculty of Business - Papers (Archive)

Faculty of Business and Law

$1-1-2014$

Ethnic or political fractionalisation? A district level analysis of the provision of public goods in Sri Lanka

Arusha Cooray

University of Wollongong, arusha@uow.edu.au

Follow this and additional works at: https://ro.uow.edu.au/buspapers

Part of the Business Commons

Research Online is the open access institutional repository for the University of Wollongong. For further information contact the UOW Library: research-pubs@uow.edu.au 


\title{
Ethnic or political fractionalisation? A district level analysis of the provision of public goods in Sri Lanka
}

\author{
Abstract \\ This study investigates the influence of ethnic and political fractionalisation on the provision of public \\ goods at a district level in Sri Lanka. Evidence shows that political fractionalisation has a greater negative \\ impact on the provision of public goods compared with ethnic fractionalisation. Similarly, political \\ polarisation has a greater negative effect on the provision of public goods compared with ethnic \\ polarisation. The interaction between ethnic and political measures suggests that political \\ fractionalisation (political polarisation) exacerbates the negative effects of ethnic fractionalisation (ethnic \\ polarisation) on the provision of public goods. The ethnolinguistic fractionalisation (ELF) index assumes \\ greater statistical significance under fixed effects estimation suggesting greater within district effects in \\ the relationship between ELF and public good provision.
}

\section{Keywords}

sri, goods, public, provision, analysis, lanka, level, ethnic, district, fractionalisation, political

\section{Disciplines \\ Business}

\section{Publication Details}

Cooray, A. (2014). Ethnic or political fractionalisation? A district level analysis of the provision of public goods in Sri Lanka. Growth and Change: a journal of urban and regional policy, 45 (4), 640-666. 
ETHNIC OR POLITICAL FRACTIONALISATION? A DISTRICT LEVEL

ANALYSIS OF THE PROVISION OF PUBLIC GOODS IN SRI LANKA

\author{
Arusha Cooray* \\ School of Economics, University of Wollongong, NSW, 2522, Australia \\ Centre for Applied Macroeconomic Analysis, Australian National University, Canberra, ACT, 0200, \\ Australia
}

Correspondence: School of Economics, University of Wollongong, Wollongong, NSW 2522, Tel: + 61-2-42214017; E-mail: arusha@uow.edu.au.

I wish to thank two annonymous referees, Leelananda De Silva and S..Meegama for valuable suggestions. 


\title{
ETHNIC OR POLITICAL FRACTIONALISATION? A DISTRICT LEVEL ANALYSIS OF THE PROVISION OF PUBLIC GOODS IN SRI LANKA
}

\begin{abstract}
:
This study investigates the influence of ethnic and political fractionalisation on the provision of public goods at a district level in Sri Lanka. Evidence shows that political fractionalisation has a greater negative impact on the provision of public goods compared to ethnic fractionalisation. Similarly, political polarisation has a greater negative effect on the provision of public goods compared to ethnic polarisation. The interaction between the ethnic and political measures suggest that political fractionalisation (political polarisation) exacerbates the negative effects of ethnic fractionalization (ethnic polarisation) on the provision of public goods. The ethnolinguistic fractionalisation (ELF) index assumes greater statistical significance under fixed effects estimation suggesting greater within district effects in the relationship between ELF and public good provision.
\end{abstract}

Keywords: ethnolinguistic fractionalisation, political fractionalisation, public goods, Sri Lanka

JEL Codes: H41, P16 


\section{Introduction}

There has been an extensive literature on the negative effects of ethnic divisions on economic outcomes - Easterly and Levine (1997), and Collier (2000) on economic growth; Alesena et al. (1999), Alesina and La Ferrara (2000), Banerjee et al. (2005), Banerjee and Somanathan (2007), Miguel and Gugerty (2004) on public good provision; Canning and Fay (1993), Mauro (1995), La Porta et al. (1999) on government activity and the quality of institutions. The general conclusion of these studies has been that ethnic divisions lead to sub-optimal economic outcomes due to a lack of consensus among different ethnic groups. There are several channels through which ethnic fractionalisation could affect the provision of public goods. Banerjee and Somanathan (2008) emphasise political differences; Dincer (2008) corruption; Kimenyi (2006) the quality of governance; Easterly and Levine (1997) government policies and conflict among ethic groups which can adversely affect the delivery of public goods; Alesina et al. (1999) and Alesina and La Ferrara (2000) different preferences with regard to public goods which can lead to lower funds being channelled to public good provision; Dincer and Lambert (2012) income inequality which can affect the distribution of public goods; and Bobo and Klugel (1993) emphasise competition between different ethnic groups for scarce resources.

A related literature questions as to what the best measure is of ethnic divisions. The studies of Alesena et al. (1999), Alesina and La Ferrara (2000), Banerjee et al. (2005), Banerjee and Somanathan use a fractionalization index. The most commonly used fractionalization measure is based on the probability that two randomly drawn individuals from a population come from two different groups. The theoretical maximum is reached at a value of 1 when each person belongs to a different group (see Aleseina and la Ferrara 2000, Alesina et al. 1999). As opposed to this, Esteban and Ray (1994) and Garcia-Montalvo and Reynal-Querol 
(2002) put forward a measure of polarization according to which a maximum is reached when two equally sized groups face each other. The studies of Dincer (2008) and Dincer and Lambert (2012) use both measures of heterogeneity. The present study uses both measures in an attempt to investigate the effects of heterogeneity on public good provision.

The literature further suggests that political divisions often reflect social divides (Banerjee and Somanathan 2008). Collier (2000) observes that political institutions are more important in deeply divided societies in comparison to relatively homogenous societies due to the fact that high levels of democracy in homogenous societies have the ability to offset the adverse effects of high levels of fractionalisation. Aghion et al. (2004) in an analysis of the degree to which societies choose to delegate power to their leaders, argue that political systems could insulate certain ethnic groups from participating in the political process in more fragmented societies. Annett (2001) shows that higher levels of ethnic fractionalization can lead to greater political instability to which governments may react, by increasing consumption expenditure as a buffer against that political instability. The political science literature moreover, shows that ethnic divisions are closely related to the structure of political party systems (Horowitz 1993, Mozaffar et al. 2003, Posner 2007). According to this literature, electoral institutions can either moderate or strengthen the negative impact of ethnic divisions on public outlook towards democratic systems.

Accordingly, the literature suggests that political institutions and ethnic fragmentation are inextricably interwoven. Political competition can therefore undermine the provision of public goods in an ethnically divided society. The objective of the present study is to investigate the influence of ethnic and political divisions on the provision of public goods in Sri Lanka. Sri Lanka is particularly relevant for a study of this nature because: (1) it has a 
deeply divided society as reflected by 26 years of civil war between the majority Sinhalese and the country's largest minority group, the Tamils; (2) the political party system appears to reflect this ethnic division (see Uyangoda 2010); (3) it has unusually high achievements in health and education despite being a low income country. The life expectancy at birth currently stands at 74 years; the infant mortality rate is 13 per 1000 live births; and the literacy rate is 89 percent (World Development Indicators 2011). Sri Lanka is considered as a model of a successful welfare state mainly due to the Sri Lanka government's commitment to the free provision of health services, education, and food subsidies since independence. There are however, district level disparities in public good provision, and the present study looks at ethnic and political conflict as possible explanations for this.

This is the first study to investigate the influence of ethnic and political divisions on the provision of pubic goods in Sri Lanka. The data used in this study is drawn primarily from the Department of Census and Statistics, Sri Lanka. Data for the census years 1953, 1963, 1971, 1981, 2001 and the year 2006/2007 covering the 25 districts of Sri Lanka are used. Results are tested for robustness in a number of ways. Several additional control variables are used to capture a range of possible factors affecting public good provision, an interaction term for ethnolinguistic fractionalisation (ELF) x political fractionalisation is incorporated to see if political fractionalisation exacerbates the negative effects of ELF on public good provision, the estimation is carried out by replacing the ELF and political fractionalisation indices with ethnic polarisation and political polarisation indices, the existence of a nonlinear relationship between the provision of public goods and fractionalisation are also investigated (see Dincer 2008). Given the use of district level data, fixed effects estimation is used to account for district level fixed effects. 
The rest of this study is structured as follows. Section 2 provides a background to the Sri Lankan ethnic and political structure. Section 3 describes the data. Section 4 evaluates the empirical results and Section 5 concludes.

\section{Background}

Sri Lanka is a low middle income nation which ranks high in terms of human development. It was first colonised by the Portuguese, then the Dutch and finally the British. The Sinhalese make up $73.9 \%$ of the population, Tamils $12.7 \%$, Indian Tamils $5.5 \%{ }^{1}$, Moor (Muslim) 7.1\%, Burgher $0.2 \%^{2}$, Malay $0.3 \%$ and other ethnic groups $0.3 \%$ (Department of Census and Statistics, Population Census 2001). According to historical anecdotes, the Sinhalese-Tamil conflict dates back to the period of the kingdoms. When the Portuguese invaded Sri Lanka in 1505, the majority of the Tamil people were concentrated in the Northern and Eastern parts of the country and the Sinhalese resided in the in the rest of the country (Singer 1992, DeVotta 2000). The British followed a divide and rule policy under which they favoured the Tamil minority. Therefore at independence, the Tamil community disproportionately held the majority of jobs in public service. Independence led to a resurgence of nationalism with calls for the need to restore Buddhism and the Sinhala language to their rightful place. This culminated in the enactment of the 1956 'Sinhala only' legislation by SWRD Bandaranaike of the Sri Lanka Freedom Party (SLFP), according to which Sinhala was established as the only official language for administrative purposes. This was aimed at capturing the votes of the Sinhala educated community who felt marginalised by the English speaking elites of all ethnic groups (International Crisis Group 2007). The disastrous consequences that this had, leading to feelings of marginalism by the largest ethnic minority group, the Tamils, resulted in a civil conflict which lasted 26 years not at the time, foreseen by Sri Lankan politicians.

\footnotetext{
${ }^{1}$ The Indian Tamil people were brought in by the British colonizers to work on the tea plantations.

${ }^{2}$ Descendants of the Dutch and Portuguese.
} 
Sri Lankan society is divided along race, religion, caste and class lines. Since independence Sri Lanka has had a two party system. The conservative United National Party (UNP) formed in 1947 and the socialist Sri Lanka Freedom Party (SLFP) in 1952, alternating with each other for power. Since 1994 however, the two major parties have failed to gain a clear majority and have formed coalition governments with smaller parties to come into power. In 1994 the SLFP came into power by forming a seven-party, leftist coalition called the People's Alliance (PA). In 2001 the UNP formed a coalition government with the Sri Lanka Muslim Congress's (SLMC) to take control of parliament. In 2004, the SLFP formed an alliance again with several leftist parties to come into power. The North and East have been represented by Tamil parties, the All Ceylon Tamil Congress and the Federal Party. Subsequently these two parties amalgamated to become the Tamil United Liberation Front (TULF). With the civil war in 1983, the TULF leadership went into exile and a number of Tamil militant groups emerged to fill the political vacuum created by the TULF's exile. Among these militant groups that emerged as political parties to work within the arena of provincial councils and parliament are, the Eelam People's Revolutionary Front (EPRLF), People's Liberation Organisation of Tamil Eelam (PLOTE), and Eelam People’s Democratic Party (EPDP). These three parties have been active in parliamentary politics since 1987 (see Uyangoda 2010). The UNP and SLFP however, have not been able to come to a consensus for power sharing with the Tamil community. Instead they are engaged in a process of 'ethnic outbidding' maintaining to be the better representative of the majority (International Crisis Group 2007). Sri Lanka has been characterised by minority coalitions governments headed by the UNP and SLFP and the presence of ideologically narrower parties since 1994. Coalition governments can undermine the provision of public goods by stalling the implementation of legislation required for public goods provision and placing pressure on the main governing party. 
Sri Lanka has 9 provinces and 25 districts in total. The Northern districts - Jaffna, Kilinochchi, Mullativu, Mannar and Vavuniya; and the Eastern district, Batticaloa, have a Tamil majority, 99.9\%, 99.9\%, 99.9\%, 51.4\%, 86.3\%, 74\% respectively. The Eastern districts, Ampara and Trincomalee, have a Moor (Muslim) majority, 41.3\% and 45.4\% respectively; and Nuwara-Eliya has an Indian Tamil majority, 50.6\% (Department of Census and Statistics Sri Lanka 2001). The rest of the districts have a Sinhalese majority. See Figure 1 for a district level division of the country.

[Figure 1, about here]

Ethnic divisions are reflected in the party system, with the Tamil minority in the Northern districts being represented primarily by the Tamil parties, and the Sinhalese by the UNP and SLFP parties. According to Horowitz (1985), political parties in divided societies which may initially reflect ethnic divisions, could contribute to widening the differences between groups because politicians may find it in their own interest to make use of these divisions to pursue their own agendas.

\section{Data and Methodology}

The study covers the census years, 1953, 1963, 1971, 1981, 2001 and the year 2006/07 at the district level. Data at the district level is not easily accessible and required going through a number of reports primarily from the Department of Census and Statistics. Data for all variables for all years were not available. Hence, the choice of variables used in the study is severely restricted by the availability of data. See Table 1 for data description and sources.

[Table 1, about here] 
The dependent variables in the study include the provision of public goods: (1) government schools, (2) government school teachers, (3) government health medical officers, (4) maternal mortality rate per 1000 live births, (4) infant mortality rate per 1000 live births used as proxies for the provision of public health, (5) water availability of main water service lines near household, (6) electricity availability of electricity lines near household and (7) road kilometerage.

The main independent variables in the study are the ethnolinguistic fractionalization index (ELF) and the political fractionalisation index. The ELF index is calculated as one minus the Herfindahl index of ethnolinguistic group shares that two people randomly drawn from the population are from distinct groups as commonly used in the literature (Alesina et al. 1999, Alesina 2004, Banerjee and Somanathan 2007 among others).

$$
\mathrm{ELF}=1-\sum_{i}^{n}\left(\text { ethnic }_{i}\right)^{2}
$$

Where ethnic $_{i}$ denotes the population share of the $\mathrm{i}^{\text {th }}$ group. Ethnic fractionalisation is calculated using the ethnic classification of the Department of Census and Statistics which divides the population into seven groups: Sinhalese, Tamil, Indian Tamil, Moor (Muslim), Burgher, Malay, Other.

The other variable of interest is the political fractionalisation index. The political fractionalisation index is calculated using the Herfindahl index in the same manner as the ELF index (see Banerjee and Somanathan 2007). The present study employs the number of seats held by each party in each district for the calculation of the political fractionalisation index rather than the vote share going to each party as in Banerjee and Somanathan (2007). 
The reason for this is that, if there are no political appointments to parliament from a particular party, candidates will not be in a position to provide public goods.

$$
\text { POLFRAC }=1-\sum_{i}^{m}\left(\text { seats }_{i}\right)^{2}
$$

Where seats ${ }_{i}$ denote the number of seats held by the $\mathrm{i}^{\text {th }}$ party. Political fractionalisation is calculated by using the number of seats held in parliament by each party in each district for the years under consideration.

Figure 2 illustrates the figures for ethnic and political fractionalisation by district for 2006. Note that political fractionalisation exceeds ethnic fractionalisation in all districts for which data are available with the exception of Trincomalee, Nuwara-Eliya and Batticaloa.

[Figures 2-5, about here]

Figure 3 illustrates the movement of the ELF and political fractionalisation indices over time. The Figure shows that the two move very closely together, however, that the political fractionalisation index is more volatile compared to the ELF index. The political fractionalisation index is higher than the ELF index in all districts with the exception of Trincomalee and Nuwera-Eliya. These two districts are the ethnically most fractionalised in Sri Lanka. Figures 4 and 5 plot the number of schools and number of medical officers respectively against the ELF index. There is a negative relationship between the number of schools and ELF index. There does not appear to be a discernible pattern between the ELF index and number of health medical officers. 
Montalvo and Reynal-Querol (2005), argue that fractionalization does not necessarily increase conflict. They find ethnic polarization to have a significant effect on civil wars. This is particularly relevant in the case of Sri Lanka where the main ethnic minority, the Tamil minority were engaged in a 26 year old civil war with the ethnic majority, the Sinhalese. The estimation is therefore also carried out by replacing the fractionalisation indices with the polarisation indices. Estaban and Ray (1994) and Garcia-Montalvo and Reynal-Querol (2002) argue that a country comprising a number of small groups may be more stable as opposed to one with two equally sized groups. Garcia-Montalvo and Reynal-Querol (2002) put forward a polarization index:

$$
E P I=1-\sum_{i=1}^{N}\left(\frac{1 / 2-s_{i}}{1 / 2}\right)^{2} s_{i}
$$

where $s_{i}$ is the share of group $i$ in the population. The EPI reaches maximum

when two equally sized groups confront each other and falls as the relationship between the groups diverges from this half and half divide. Garcia-Montalvo and Reynal-Querol (2002) show that this index is associated with ethnolinguistic fractionalization (ELF). A polarisation index is similarly constructed for political polarization (POLPI).

$$
P O L P I=1-\sum_{i=1}^{N}\left(\frac{1 / 2-x_{i}}{1 / 2}\right)^{2} x_{i}
$$

Where $x_{i}$ denotes the number of seats held by the $\mathrm{i}^{\text {th }}$ party. Figure 6 illustrates the figures for ethnic and political polarisation by district for 2006. Note that as in Figure 2, political polarisation exceeds ethnic polarisation in all districts for which data are available with the exception of Trincomalee, Nuwara-Eliya and Batticaloa. Figure 7 illustrates the movement of the EPI and political polarisation indices over time. As opposed to the fractionalisation indices, the two series tend to diverge a lot more. However, once again, the political polarisation index is more volatile compared to the EPI. 
[Figures 6-7, about here]

Table 2 presents the distribution of total and per capita public goods across districts. A preliminary examination of the data appear to support the hypothesis that greater political fractionalisation contributes to the lower provision of public goods. The districts which rank highest in terms of political fractionalisation, Trincomalee (0625), Colombo (0.615), Gampaha (0.581), Nuwera-Eliya (0.571), and Kalutara (0.540) also appear to have a lower number of schools, teachers, road kilometerage and electricity lines per capita. Nuwera-Eliya which also has a relatively high degree of ethnic fractionalisation, has a lower number of medical officers per capita, and a high maternal mortality rate.

[Table 2, about here]

Other control variables used in the study are based upon the literature (Alsesina et al. 1999, Banerjee and Somanathan 2007). Per capita mean monthly income is used to measure the level of development of a district. District size is captured by the population in each district. As a more educated population is more likely to choose better policies, the literacy rate for each district is used to measure the level of educational attainment of a district. The district level provision of public goods may be explained by the inequality in income distribution in that district. Therefore the Gini coefficient of \% of poor households are used to measure income inequality. A dummy variable is introduced for the war affected Northern and Eastern districts. This variable takes a value of 1 for the war affected years and zero otherwise.

Dincer (2008) and Dincer and Lambert (2012) find evidence of non-linear effects of ELF on corruption and income inequality. In this case, an increase in fractionalisation beyond a certain point could reduce the negative effect of ELF on the provision of public goods. In 
order to capture any non-linear effects that might be present, the model is also estimated with a squared term for ELF. Table 3 reports summary statistics for the data used in the estimation.

[Table 3, about here]

The empirical model takes the following form:

$$
Y_{D t}=\alpha+\vartheta E L F_{D t}+\varpi P L O L F R A C_{D t}+x_{D t} \beta+v_{D}+\varepsilon_{D t}
$$

where $Y_{D t}$ represents access to a particular public good in district $D$ in period $t$. ELF $F_{D t}$ represents the ethnic fractionalisation index and POLFRAC $C_{D t}$ the political fractionalisation index for district $D$ in period $t$. Robustness tests are carried out by replacing the ELF index with the EPI and the POLFRAC index with a POLPI index. Correlation between the fractionalisation and polarisation indices are reported in Table 4. The correlation between the ELF and POLFRAC indices and the EPI and the POLPI are low. There is however, a high degree of correlation between the ELF and EPI indices, and the POLFRAC and POLPI indices. Therefore the fractionalisation indices and the polarisation indices are not used together but separately in the estimation that follows.

[Table 4, about here]

All control variables mentioned in Section 3 are captured by the vector $\boldsymbol{x}_{D \mathrm{t}} \cdot V_{D}$ is a dummy variable which takes on a value of 1 for the war affected Northern and Eastern districts in the war affected years. Banerjee and Somanathan (2008) argue that political heterogeneity could reflect social heterogeneity. This suggests that political fractionalisation could further exacerbate the negative effects of ethnic fractionalisation. In Sri Lanka, ethnic divisions are reflected in the party system. The Northern districts in which there is a Tamil majority, are represented mainly by Tamil parties and the Sinhalese mainly by the UNP and the SLFP. 
There are however, several different Sinhala and Tamil parties which the index of political fractionalisation captures which cannot be captured by the measure of ethnic fractionalisation. In order to explore the effects of political divides on ethnic divisions, the political fractionalization index is also interacted with the ethnic fractionalization index. $\varepsilon_{D t}$ is a random error term that captures all other variables.

\section{Results}

As mentioned above the data cover the years, 1953, 1963, 1971, 1981, 2001 and 2006. The preliminary model is estimated using pooled OLS. Fixed effects panel data estimation is used additionally, to capture unobserved district specific effects.

\section{Pooled OLS}

The results for the regression using pooled OLS are reported in Table 5 where the dependent variables are: the number of government schools (column 1), government school teachers (columns 2), government health medical officers (column 3), the number of maternal deaths (column 4), the infant mortality rate (column 5), electricity availability of main electricity service lines near household (column 6), water availability of main water service lines near household (column 7) and road kilometerage (column 8). The data comprises an unbalanced panel. The main independent variables are the ELF index, political fractionalisation index (POLFRAC) and the interaction term between ELF and POLFRAC. A number of control variables are also included in the model. Population, to control for the size of the district, per capita income and the literacy rate to capture the level of development of the district. As pointed out by Alesina et al. (1999), fractionalisation could be a fractionalisation of income rather than ethnicity. Therefore the Gini coefficient is used to capture income distribution. A 
dummy variable is included for the war affected Northern and Eastern districts for the war affected years.

[Table 5, about here]

The results reported in Table 5 show that ELF has a statistically significant negative effect on government school teachers, the availability of electricity, and water lines. A 1 unit increase in the ethnic fractionalisation index in column (2) for example, will lead to a $0.4 \%$ fall in government school teachers. Note that the political fractionalisation index has a much greater negative statistically significant impact on the provision of public goods compared to the ELF index. A 1 unit increase in the political fractionalisation index leads to a $0.6 \%$ fall in government school teachers in column (2). Political fractionalisation has a significant negative impact on the number of government schools, school teachers, health medical officers, the availability of electricity and water lines, and a significant increase in infant mortality. The interaction of ELF with the POLFRAC index has a negative impact on the same public goods suggesting that political fractionalisation acts to increase the negative effects of ethnic fractionalisation.

The statistically significant coefficients on district size as measured by population indicate that larger districts have more government schools, teachers, health medical officers and road kilometerage. The coefficients on the literacy rate in columns (2) and (3) are statistically significant implying that more literate districts are more likely to have more school teachers and medical officers. The estimates on the Gini coefficients indicate that school teachers and medical officers are higher in districts in which there is greater inequality, and the supply of electricity is lower in districts characterised by greater inequality. Per capita income is statistically significant in all columns with the exception of column (2). The dummy variables on the Northern and Eastern districts are negative and significant in all columns with the 
exception of columns (4) and (8) suggesting that the war had a negative impact on the provision of public goods in these two regions.

[Table 6, about here]

Alesena et al. (1999) observe that the share of ethnic minorities could be strongly correlated to the ELF index so that the ELF index could be proxying for the share of minority groups. If the ethnic minority groups were proxying for the ELF index, or alternatively the political fractionalisation index, then these indices would cease to be statistically significant with the inclusion of ethnic minority groups in the estimation. Hence, in order to investigate if the ELF or political fractionalisation index are proxying for ethnic minority groups, the \% of Tamil, Indian Tamil and Moors are included in the estimation in Table 6. In Table 5, the ELF index was statistically significant in columns (2), (6) and (7). The ELF index gains greater statistical significance in Table 6, showing that an increase in ELF leads to a fall in government schools, teachers, health medical officers, electricity and water availability. The political fractionalisation index continues to be statistically significant with respect to the same variables as before. It can be concluded that the percentage of ethnic minority groups are not proxying for the ELF index, as the ELF gains greater significance rather than losing statistical significance with the incorporation of the \% of minority groups. Once again, political fractionalisation has a larger negative statistically significant impact on the provision of public services compared to the ELF index. The interaction of the ELF*POLFRAC has a negative significant impact on the provision of public schools, school teachers, medical officers, water, electricity supply and on the maternal and infant mortality rates. The coefficient on Tamil is negative and statistically significant, in columns (1), (4), (6) and (8), suggesting that the number of government schools, electricity availability and road connections to other cities are lower if Tamil. For Indian Tamil community, government teachers, health medical officers, electricity, water availability and road connections are 
lower, and for the Muslim community, health medical officers and electricity availability are lower and maternal deaths are also lower.

The coefficient on population has a statistically significant positive effect on schools, school teachers, medical officers, maternal deaths and road kilometerage. Larger districts as measured by population have more schools, school teachers, medical officers and are better connected to other cities. They also have a larger number of maternal deaths. The coefficients on the literacy rate in columns (1)-(4) are statistically significant suggesting that more literate districts are more likely to have more schools, school teachers, medical officers and fewer maternal deaths. The estimates on the Gini coefficient are statistically significant in columns (1), (2), (4) and (6). The provision of schools and school teachers are higher and the supply of water lower the greater the inequality. Maternal deaths are higher the greater the inequality. Per capita income is not statistically significant. The dummy variables for the Northern and Eastern districts are negative in columns (1), (2), (5)-(7) suggesting that the provision of schools, teachers, electricity and water were lower in these areas in the war affected years and infant deaths were higher.

Additional control variables which included, population density, the \% of urban and rural population and land ownership were also explored with. The coefficients on population density, the higher the provision of public goods. The coefficients on land ownership and urban-rural population were not statistically significant.

Table 7 reports results for non-linearity effects in ELF. The ELF index is statistically significant in columns (2), (6) and (7) . The political fractionalisation index continues to be statistically significant in all columns except for columns (4) and (8). The squared term on the 
ELF index is statistically significant at the $10 \%$ level only in the case of health medical officers. There is in general, no evidence of non-linear effects of ELF on the provision of public goods.

\section{[Tables 7-8, about here]}

Table 8 replicates the estimation carried out in Table 5, replacing the ELF index with the EPI and the political fractionalisation index with a political polarisation index. The coefficients on the EPI are statistically significant at the 5\% level in columns (1) and (3) indicating a negative effect on government school and health medical officers. The political polarisation index assumes greater statistical significance compared to the ethnic EPI as with the political fractionalisation index. The interaction terms between the EPI and political polarisation index is statistically significant in all columns with the exception of column (4) suggesting that political polarisation magnifies the effects of ethnic polarisation having an adverse effect on public good provision.

\section{Fixed Effects Estimation}

Next fixed effects estimation is carried out to account for district level time invariant unobservable influences on the provision of public goods. The fixed effects estimation is replicated on the estimation in Table 5. The results are reported in Table 9.

[Table 9, about here]

The fixed effects estimation yields better results with the coefficient on the ELF index assuming statistical significance in columns (1), (2), (5), (6), (7) and (8), suggesting greater within district effects in the relation between ELF and public good provision. Greater ELF leads to a lower provision of schools, teachers, electricity and water, and higher infant mortality. Increased political fractionalisation leads to a lower supply of schools, teachers, 
health medical officers, electricity, water and higher infant mortality rates. Larger districts as measured by population are better off with respect to schools, teachers, medical officers, and electricity. Per capita income is statistically significant in all columns except (3) and (7) suggesting that higher income leads to increased schools, school teachers, electricity and road kilometerage and lower maternal and infant mortality.

\section{Conclusions}

This study investigates the effect of ELF and political fractionalisation on the provision of public goods in Sri Lanka. The impact of ethnic polarization and political polarisation on public good provision are also examined. The political fractionalisation and political polarisation indices have a greater adverse effect on the provision of public goods compared to the ELF and EPI. While the political fractionalisation index has a consistently negative effect on public good provision under all three estimation methods, the ELF index assumes greater statistical significance under fixed-effects estimation. The results suggest that the relationship between ELF and public good provision is stronger within given districts suggesting the importance of district specific effects in the relation between ELF and public good provision ${ }^{3}$. While the results are consistent with the previous literature (for example, Alesena et al. 1999, Alesina and La Ferrara 2000, Banerjee et al. 2005, Banerjee and Somanathan 2007), the present study offers a new dimension to the existing literature with regard to interpretation. The results also suggest that ethnic and political fractionalisation cannot be considered in isolation of one another. Since 1994, the two main political parties in

\footnotetext{
${ }^{3}$ This is supported by Forbes (2000) who finds that when country effects are incorporated into a pooled OLS model, the relationship between inequality and growth becomes positive and significant suggesting the importance of country specific effects.
} 
Sri Lanka have had to accommodate the needs of a number of smaller less moderate parties which may have potentially slowed down the provision of public goods in particular districts. Therefore policymakers should consider the problems arising from fractionalised (or polarised) party systems in their attempts to achieve sustainable growth. With the cessation of the war in 2009, Sri Lanka now faces the task of achieving a sustainable growth rate. While Sri Lanka is regarded as a model of a welfare state, it can be argued that public service provision can be enhanced to a greater degree, particularly districts in which political and social divides are high, if the two main political parties in consultation with other parties, are able to reach common ground concerning successful democratization. This would depend to a large degree upon the construction of institutions that promote the rule of law and restrain the concentration of power. "The design of these institutions needs to be based on a realistic appreciation of the nature and power of the interests involved” (Barnes 2001). 


\section{References}

Aghion, P., A, Alesenia, and F. Trebbi. 2004. Endogenous political institutions. Quarterly Journal of Economics 119(2): 565-611.

Alesina, A. 2004. Ethnic diversity and economic performance. NBER Working Paper No. 10313.

Alesina, A., and E. La Ferrara. 2000. Participation in heterogeneous communities. Quarterly Journal of Economics 115 (3): 847-904.

Alesina, A., R. Baqir, and W. Easterly. 1999. Public goods and ethnic divisions. Quarterly Journal of Economics 114(4): 1243-1284.

Annett, A. 2001. Social fractionalization, political instability, and the size of the government. IMF Staff Papers 48(3): 561-592.

Arellano, M., and O. Bover. 1995. Another look at the instrumental variables estimation of error components models. Journal of Econometrics 68(1): 29-51.

Banerjee, A., L. Iyer, and R. Somanathan. 2005. History, social divisions and public goods in rural India. Journal of the European Economic Association 3(2-3): 639-647.

Banerjee, A., and R. Somanathan. 2007. The political economics of public goods: Some evidence from India. Journal of Development Economics 82(2): 287-314.

Barnes, S. 2001. The contribution of democracy to rebuilding postconflict societies. American Journal of International Law 95(1): 86-101.

Blundell, R., and S. Bond. 1998. Initial conditions and moment restrictions in dynamic panel data models. Journal of Econometrics 87(1): 115-143.

Bobo, L., and J. R. Kluegel. 1993. Opposition to race targeting: self interest, stratification ideology, or racial attitudes. American Sociological Review 58(4): 443-464.

Canning, D., and M. Fay. 1993. The effects of transportation networks on economic growth. Columbia University Working Paper.

Collier, P. 2000. Ethnicity, politics and economic performance. Economics and Politics 12(3): 225-245.

Collier, P., and A. Hoeffler. 1998. On economic causes of civil war. Oxford Economic Papers 50(4): 563-573.

DeVotta, N. 2000. Control democracy, institutional decay, and the quest for Eelam:

Explaining ethnic conflict in Sri Lanka. Pacific Affairs 73(1): 55-76.

Dincer, O., 2008. Ethnic and religious diversity and corruption. Economics Letters 99(1): 98102. 
Dincer, O., and P. Lambert. 2012. Taking care of your own ethnic and religious heterogeneity and income inequality. Journal of Economic Studies 39(3): 290-313.

Easterly, W., and R. Levine. 1997. Africa's growth tragedy: Policies and ethnic divisions. Quarterly Journal of Economics 112(4): 1203-1250.

Forbes, K. 2000. A reassessment of the relationship between inequality and growth. American Economic Review 90(4): 869-887.

Hausman, J. 1978. Specification tests in econometrics. Econometrica 46(6): 1251-1271.

Horowitz, D. 1993. Democracy in divided societies. Journal of Democracy 4(4): 18-38.

Horowitz, D. 1985. Ethnic groups in conflict. Berkeley: University of California Press.

International Crisis Group. 2007. Sri Lanka: Sinhala nationalism and the elusive Southern consensus. Asia Report No. 141.

Kimenyi, M. 2006. Ethnicity, governance and the provision of public goods. Journal of African Economies 15(1): 62-99.

La Porta, R. F., A. Lopez de Silanes, R. Shleifer, and R. Vishny. 1999. The quality of government. Journal of Law, Economics and Organization 15(1): 222-279.

Mauro, P. 1995. Corruption and growth. Quarterly Journal of Economics 110(3): 681-712.

Miguel, E. and M. Gugerty. 2005. Ethnic diversity, social sanctions, and public goods in Kenya. Journal of Public Economics 89(11-12): 2325-2368.

Montalvo, J.G., and M. Reynal-Querol. 2002. Why ethnic fractionalization? Polarization, Ethnic Conflict and Growth, UPF Working Paper 660.

Mozaffar, S., J. Scarritt, and G. Galaich. 2003. Electoral institutions, ethnopolitical cleavages, and party systems in Africa's emerging democracies. American Political Science Review 97(3): 379-390.

Piazza, J. 2006. Rooted in poverty?: Terrorism, poor economic development, and social cleavages. Terrorism and Political Violence 18(1): 159-177.

Posner, D. 2007. Regime change and ethnic cleavages in Africa. Comparative Political Studies 40(1): 1302-1327.

Sargan, J. 1964. Wages and Prices in the United Kingdom: A Study in Econometric Methodology. In Economic Analysis for National Economic Planning, ed. P. Hart., E. Mills, and J. Whitaker. Butterworth: London.

Singer, M. 1992. Sri Lanka’s Tamil-Sinhalese ethnic conflict. Asian Survey 32(8): 712-722.

World Bank. 2011. World Development Indicators. 
Figure 1: District Level Division of Sri Lanka

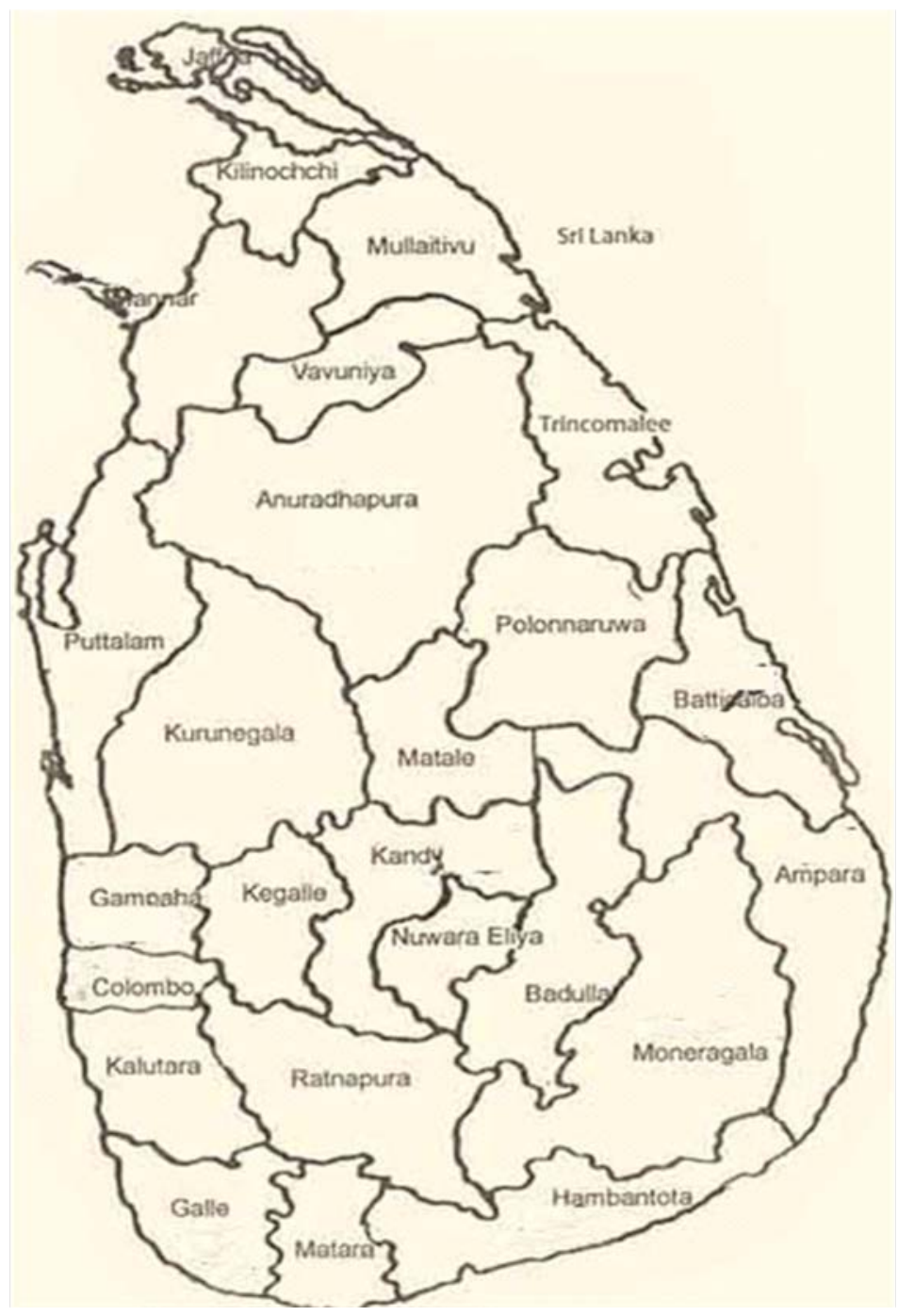


Figure 2: Ethnic and Political Fractionalisation Index by District 2006

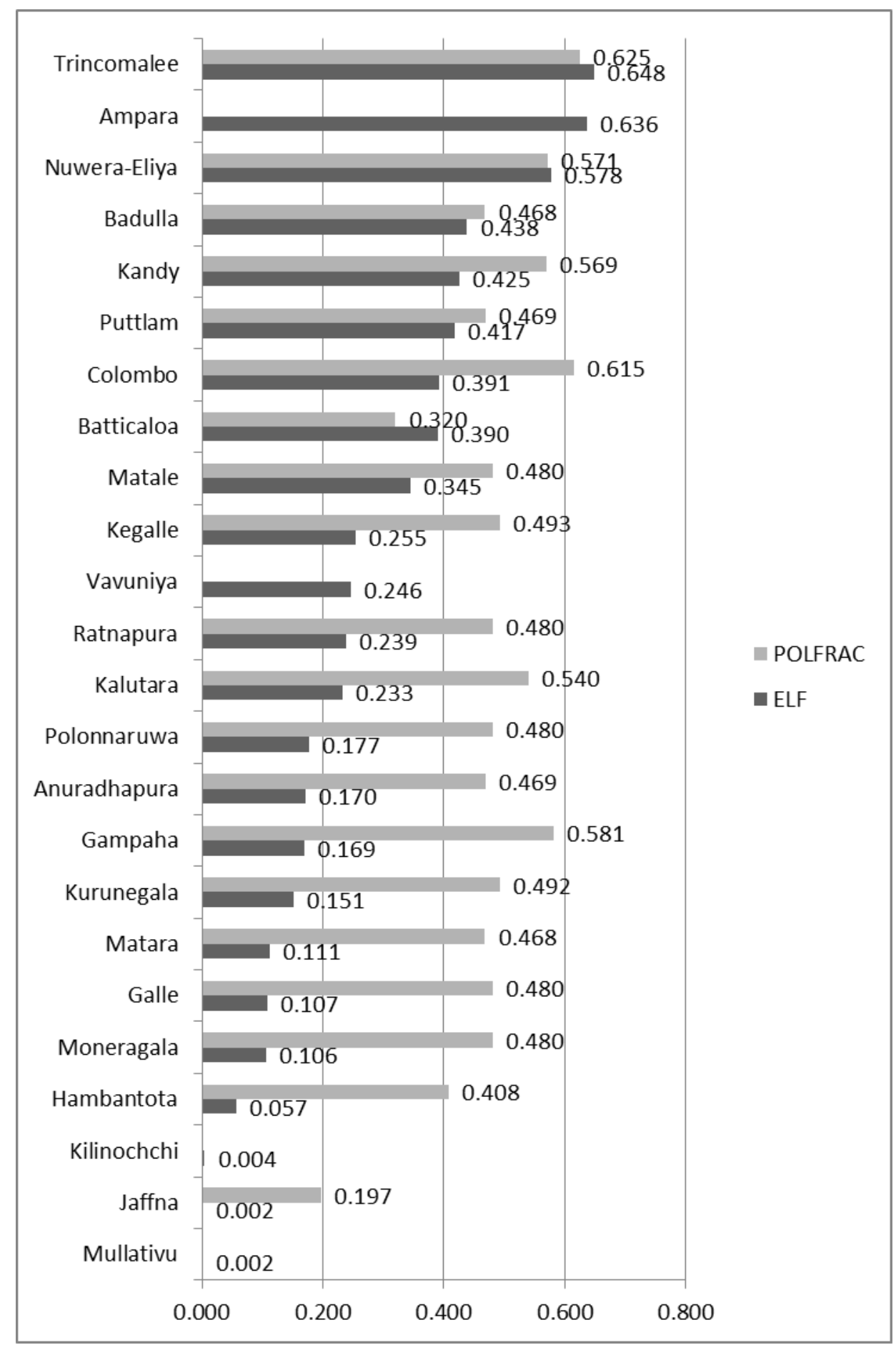


Figure 3: Movement in ELF and Political Fractionalisation Over Time

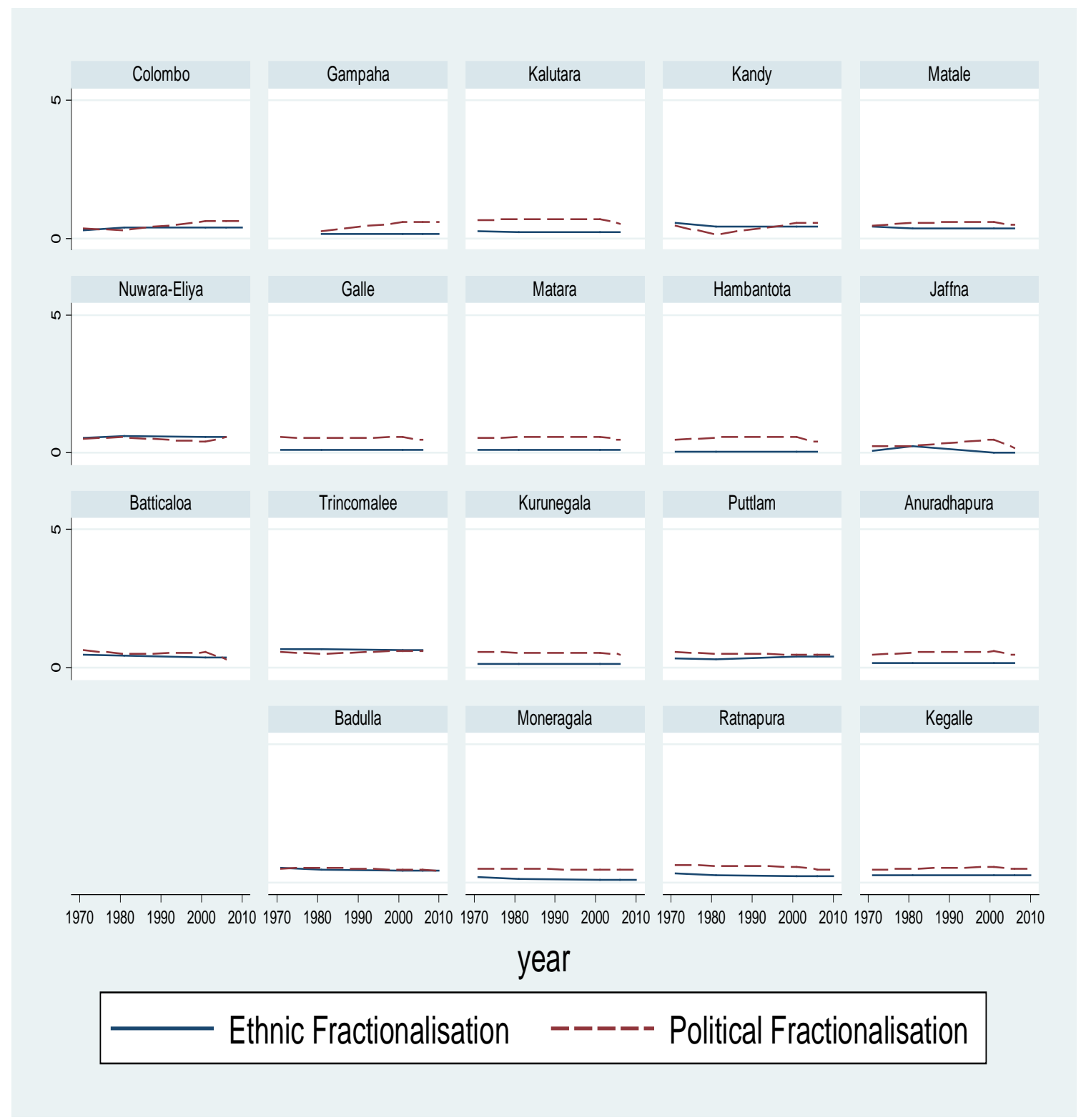


Figure 4: Ethnic Fractionalisation Index vs Number of Schools

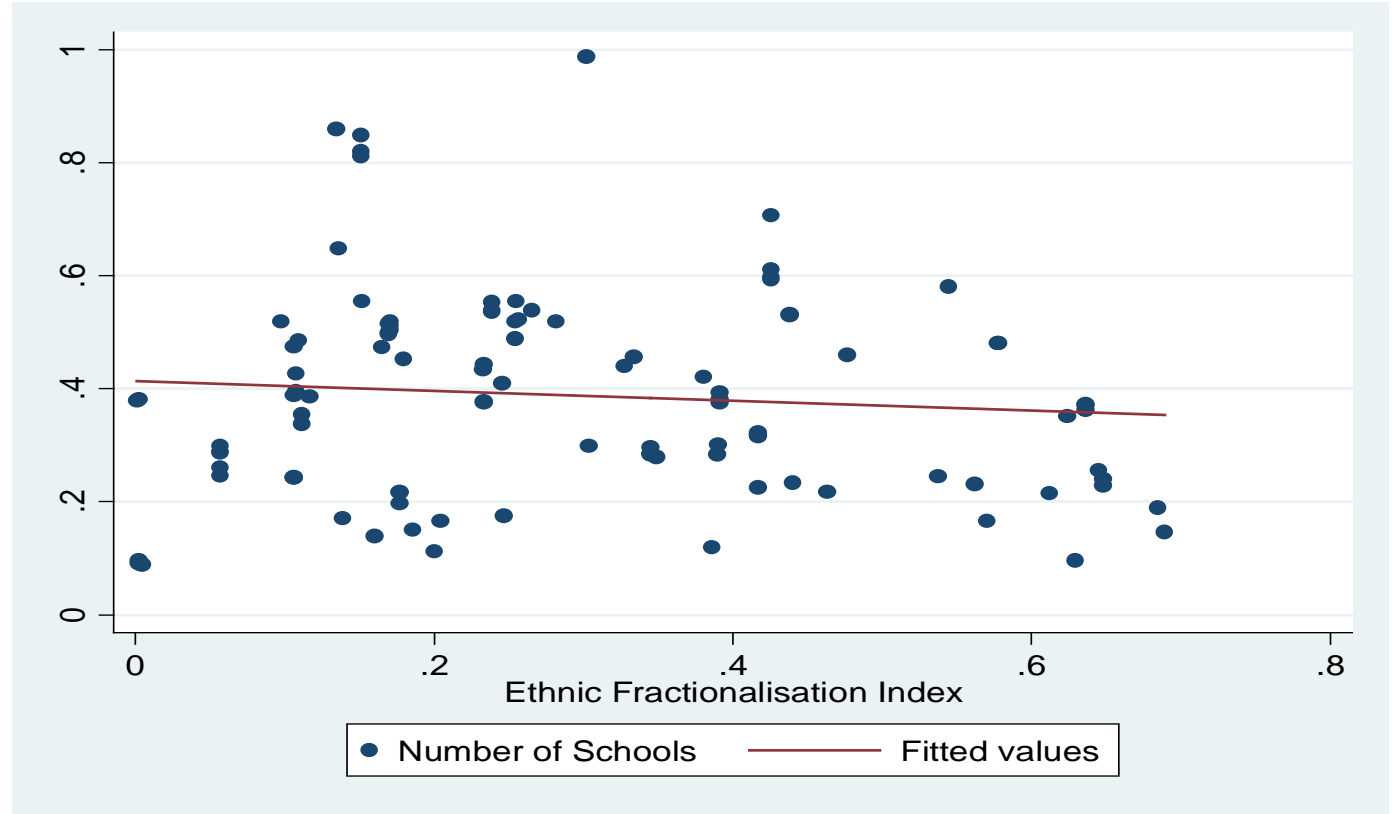

Note: the number of schools has been normalised

Figure 5: Ethnic Fractionalisation Index vs Health Medical Officers

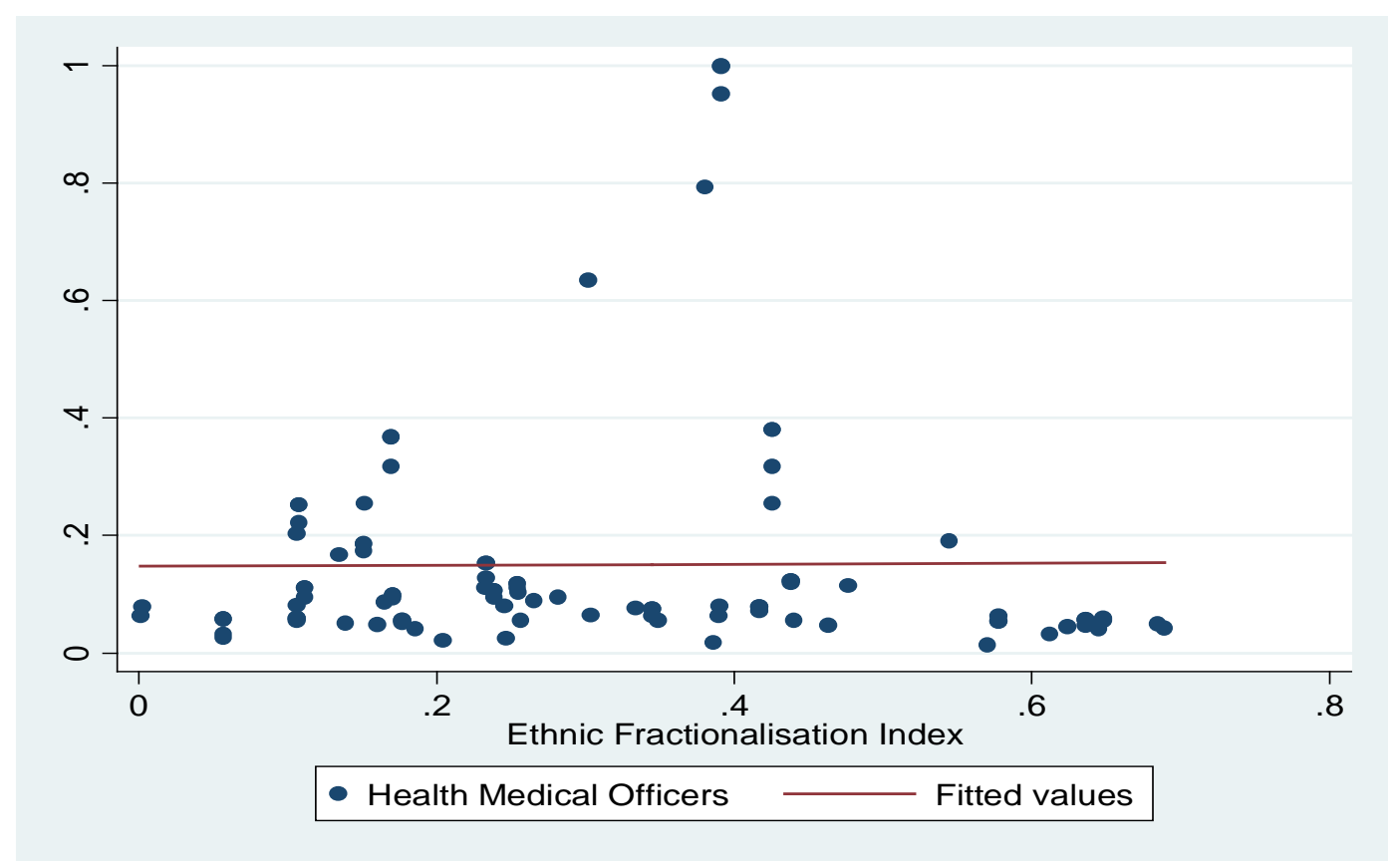

Note: Health medical officers has been normalised 
Figure 6: Ethnic and Political Polarization Index by District 2006

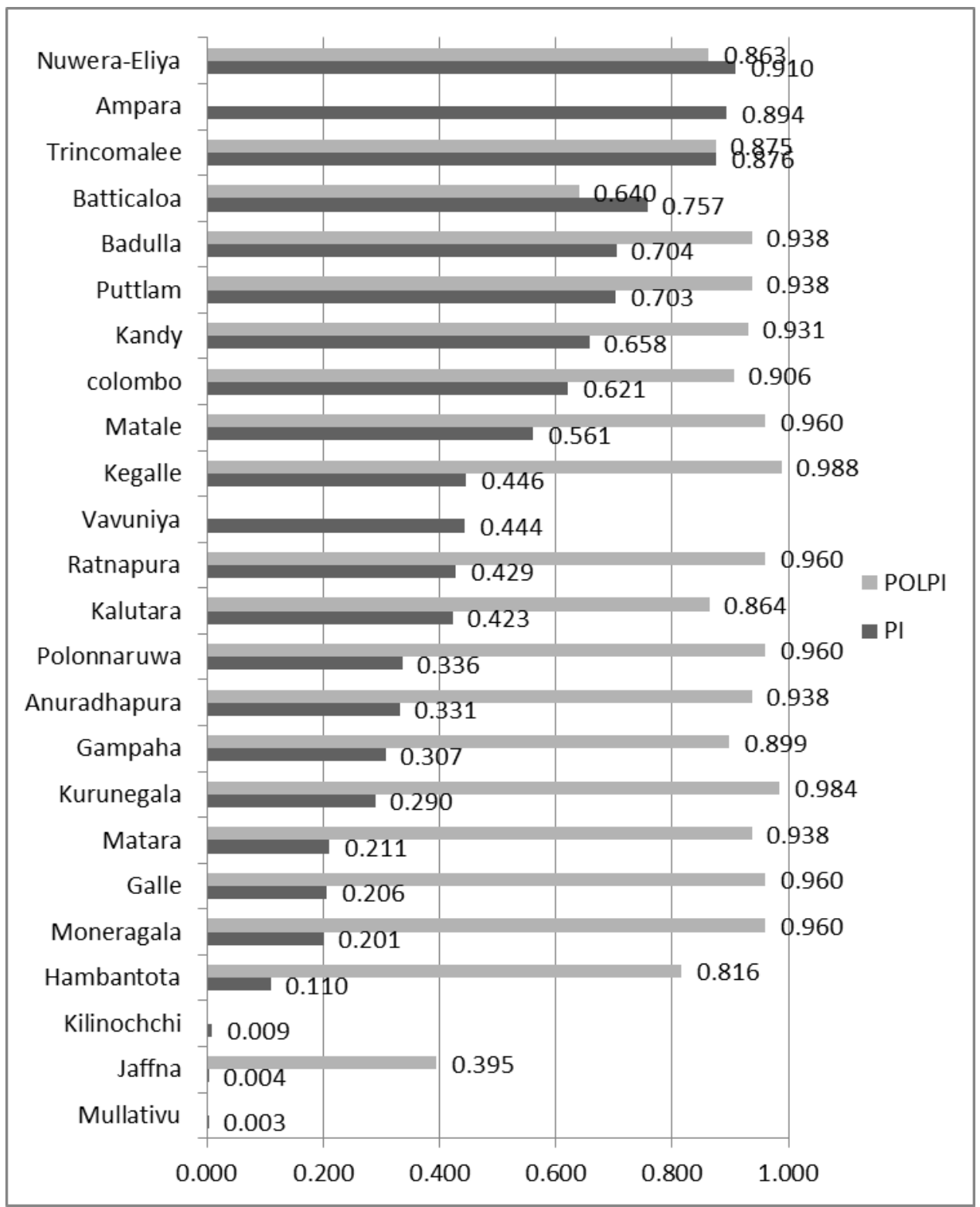


Figure 7: Movement in PI and Political Polarisation Over Time

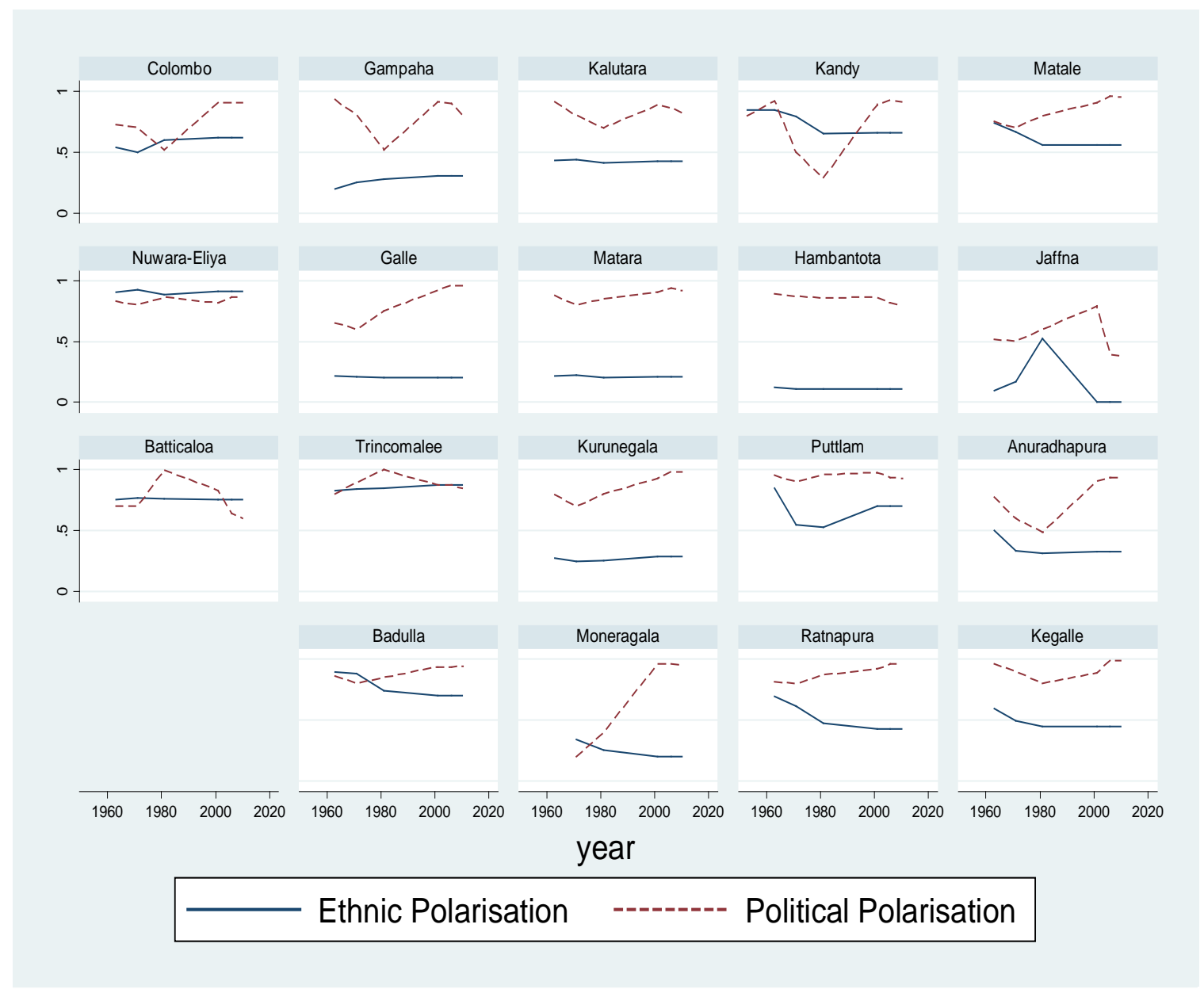


Table 1: Description of Variables used in the Study and Data Sources

\begin{tabular}{|c|c|}
\hline Data & Source \\
\hline \multicolumn{2}{|l|}{ Public Goods: } \\
\hline Number of government schools & $\begin{array}{l}\text { Department of Census and Statistics Statistical Abstracts, various } \\
\text { issues. }\end{array}$ \\
\hline $\begin{array}{l}\text { Number of government school } \\
\text { teachers }\end{array}$ & $\begin{array}{l}\text { Department of Census and Statistics Statistical Abstracts, various } \\
\text { issues. }\end{array}$ \\
\hline $\begin{array}{l}\text { Maternal mortality rate per } 1000 \\
\text { live births (used as proxy for } \\
\text { provision of public health } \\
\text { health) }\end{array}$ & $\begin{array}{l}\text { Department of Census and Statistics Statistical Abstracts, various } \\
\text { issues. }\end{array}$ \\
\hline $\begin{array}{l}\text { Infant mortality rate per } 1000 \\
\text { live births (used as proxy for } \\
\text { provision of public health } \\
\text { health) }\end{array}$ & $\begin{array}{l}\text { Department of Census and Statistics Statistical Abstracts, various } \\
\text { issues. }\end{array}$ \\
\hline Public health medical officers & $\begin{array}{l}\text { Central Bank of Sri Lanka, Economic and Social Statistics of Sri } \\
\text { Lanka, various issues }\end{array}$ \\
\hline $\begin{array}{l}\text { Water availability of main water } \\
\text { service line near household }\end{array}$ & $\begin{array}{l}\text { Department of Census and Statistics, Household Income and } \\
\text { Expenditure Surveys. }\end{array}$ \\
\hline $\begin{array}{l}\text { Electricity availability of electricity } \\
\text { line near household }\end{array}$ & $\begin{array}{l}\text { Department of Census and Statistics, Household Income and } \\
\text { Expenditure Surveys. }\end{array}$ \\
\hline Road kilometerage & $\begin{array}{l}\text { Central Bank of Sri Lanka, Economic and Social Statistics of Sri } \\
\text { Lanka, various issues. }\end{array}$ \\
\hline $\begin{array}{l}\text { Ethnic fractionalisation authors own } \\
\text { calculation using \% of each ethnic } \\
\text { group as classified by the Department of } \\
\text { Census and Statistics. }\end{array}$ & $\begin{array}{l}\text { Department of Census and Statistics Statistical Abstracts, various } \\
\text { issues. } \\
\text { Data for ethnicity Northern province 2006/2007 from Northern } \\
\text { District reports. }\end{array}$ \\
\hline $\begin{array}{l}\text { Political fractionalisation authors own } \\
\text { calculation based on the number of seats } \\
\text { secured by each party in each district }\end{array}$ & $\begin{array}{l}\text { Department of Election Sri Lanka, results of parliamentary general } \\
\text { elections. }\end{array}$ \\
\hline $\begin{array}{l}\text { Ethnic polarization authors own } \\
\text { calculation using proportion of each } \\
\text { ethnic group as classified by the } \\
\text { Department of Census and Statistics. } \\
\end{array}$ & $\begin{array}{l}\text { Department of Census and Statistics Statistical Abstracts, various } \\
\text { issues. } \\
\text { Data for ethnicity Northern province 2006/2007 from Northern } \\
\text { District reports. }\end{array}$ \\
\hline $\begin{array}{l}\text { Political polarisation authors own } \\
\text { calculation based on the number of seats } \\
\text { secured by each party in each district }\end{array}$ & $\begin{array}{l}\text { Department of Election Sri Lanka, results of parliamentary general } \\
\text { elections. }\end{array}$ \\
\hline Per capita mean monthly income & $\begin{array}{l}\text { Department of Census and Statistics, Household Income and } \\
\text { Expenditure Surveys. } \\
\text { Household Income and Expenditure Survey for Northern and } \\
\text { Eastern Province 2002/2003. }\end{array}$ \\
\hline Literacy rate & $\begin{array}{l}\text { Department of Census and Statistics Statistical Abstracts, various } \\
\text { issues. }\end{array}$ \\
\hline $\begin{array}{l}\text { Income inequality - Gini coefficient of } \\
\text { per capita income }\end{array}$ & $\begin{array}{l}\text { Department of Census and Statistics, Household Income and } \\
\text { Expenditure Surveys } \\
\text { Sri Lanka Integrated Survey 1999/2000. }\end{array}$ \\
\hline Population (000) & $\begin{array}{l}\text { Department of Census and Statistics Statistical Abstracts, various } \\
\text { issues. }\end{array}$ \\
\hline
\end{tabular}


Table 2: Public Goods (Total and Per Capita) by District as of 2006

\begin{tabular}{|c|c|c|c|c|c|c|c|}
\hline District & $\begin{array}{l}\text { Total } \\
\text { Govt } \\
\text { Schools }\end{array}$ & $\begin{array}{l}\text { Govt } \\
\text { Schools } \\
\text { Per } \\
\text { Capita }\end{array}$ & Teachers & $\begin{array}{l}\text { Teachers } \\
\text { per } \\
\text { Capita }\end{array}$ & $\begin{array}{l}\text { Health } \\
\text { Medical } \\
\text { Officers }\end{array}$ & $\begin{array}{l}\text { Health } \\
\text { Medical } \\
\text { Officers } \\
\text { Per } \\
\text { Capita } \\
\end{array}$ & $\begin{array}{l}\text { Maternal } \\
\text { Deaths } \\
\text { per } 1000\end{array}$ \\
\hline Colombo & 410 & 0.17 & 14985 & 6.10 & 3145 & 1.28 & 0.03 \\
\hline Gampaha & 537 & 0.25 & 14010 & 6.55 & 1160 & 0.54 & 0.07 \\
\hline Kalutara & 406 & 0.37 & 9670 & 8.70 & 480 & 0.43 & 0.19 \\
\hline Kandy & 643 & 0.47 & 15318 & 11.10 & 1197 & 0.87 & 0.1 \\
\hline Matale & 307 & 0.64 & 5365 & 11.25 & 237 & 0.50 & 0.43 \\
\hline Nuwera-Eliya & 517 & 0.70 & 6180 & 8.33 & 172 & 0.23 & 0.61 \\
\hline Galle & 422 & 0.40 & 10850 & 10.31 & 794 & 0.75 & 0.15 \\
\hline Matara & 363 & 0.45 & 9539 & 11.73 & 350 & 0.43 & 0.34 \\
\hline Hambantota & 308 & 0.56 & 6859 & 12.43 & 184 & 0.33 & 0.13 \\
\hline Jaffna & 410 & 0.68 & 5746 & 9.59 & 246 & 0.41 & 0.32 \\
\hline Vavuniya & 188 & 1.13 & 1806 & 10.88 & 77 & 0.46 & 0.25 \\
\hline Mullativu & 103 & 0.70 & 987 & 6.71 & - & - & 0.42 \\
\hline Kilinochchi & 96 & 0.66 & - & - & - & - & 0.93 \\
\hline Batticaloa & 323 & 0.62 & 4250 & 8.13 & 252 & 0.48 & 0.15 \\
\hline Ampara & 390 & 0.63 & 6541 & 10.64 & 180 & 0.29 & 0.31 \\
\hline Trincomalee & 258 & 0.73 & 3935 & 11.08 & 186 & 0.52 & 0.37 \\
\hline Kurunegala & 881 & 0.58 & 18555 & 12.18 & 587 & 0.39 & 0.08 \\
\hline Puttlam & 340 & 0.45 & 6253 & 8.32 & 247 & 0.33 & 0.08 \\
\hline Anuradhapura & 550 & 0.69 & 9175 & 11.45 & 311 & 0.39 & 0.12 \\
\hline Polonnaruwa & 232 & 0.59 & 3467 & 8.78 & 174 & 0.44 & 0.14 \\
\hline Badulla & 569 & 0.67 & 9788 & 11.52 & 388 & 0.46 & 0.34 \\
\hline Moneragala & 262 & 0.62 & 4632 & 10.90 & 187 & 0.44 & 0.14 \\
\hline Ratnapura & 579 & 0.53 & 10399 & 9.58 & 335 & 0.31 & 0.33 \\
\hline Kegalle & 525 & 0.65 & 9396 & 11.72 & 371 & 0.46 & 0.52 \\
\hline
\end{tabular}


Table 2 continued: Public Goods (Total and Per Capita) by District

\begin{tabular}{|c|c|c|c|c|c|c|c|}
\hline District & $\begin{array}{l}\text { Infant } \\
\text { Mortality } \\
\text { per } 1000 \\
\text { Live } \\
\text { Births } \\
\end{array}$ & Road Km. & $\begin{array}{l}\text { Road } \\
\text { Km per } \\
\text { Capita }\end{array}$ & $\begin{array}{l}\text { Water } \\
\text { Lines }\end{array}$ & $\begin{array}{l}\text { Water } \\
\text { Lines } \\
\text { per } \\
\text { Capita }\end{array}$ & $\begin{array}{l}\text { Electricity } \\
\text { Lines }\end{array}$ & $\begin{array}{l}\text { Electricity } \\
\text { Lines per } \\
\text { Capita }\end{array}$ \\
\hline Colombo & 15.0 & 823 & 0.34 & 89.4 & 0.04 & 99.8 & 0.04 \\
\hline Gampaha & 6.1 & 1614 & 0.75 & 45.7 & 0.02 & 99.4 & 0.05 \\
\hline Kalutara & 4.1 & 1068 & 0.96 & 36.8 & 0.03 & 94.1 & 0.08 \\
\hline Kandy & 15.4 & 2011 & 1.46 & 61.0 & 0.04 & 94.7 & 0.07 \\
\hline Matale & 10.3 & 853 & 1.79 & 41.9 & 0.09 & 86.8 & 0.18 \\
\hline Nuwera-Eliya & 15.6 & 1103 & 1.49 & 64.1 & 0.09 & 91.1 & 0.12 \\
\hline Galle & 10.8 & 1150 & 1.09 & 33.5 & 0.03 & 92.7 & 0.09 \\
\hline Matara & 8.4 & 934 & 1.15 & 46.2 & 0.06 & 95.1 & 0.12 \\
\hline Hambantota & 6.7 & 1073 & 1.94 & 75.2 & 0.14 & 89.7 & 0.16 \\
\hline Jaffna & 5.7 & 1230 & 2.05 & - & - & - & - \\
\hline Vavuniya & 8.0 & 604 & 3.64 & - & - & - & - \\
\hline Mullativu & 2.5 & 567 & 3.86 & - & - & - & - \\
\hline Kilinochchi & 1.2 & 281 & 1.92 & - & - & - & - \\
\hline Batticaloa & 21.1 & 652 & 1.25 & 17.0 & 0.03 & 93.1 & 0.18 \\
\hline Ampara & 5.9 & 738 & 1.20 & 26.1 & 0.04 & 85.4 & 0.14 \\
\hline Trincomalee & 3.4 & 856 & 2.41 & & & & \\
\hline Kurunegala & 14.2 & 2345 & 1.54 & 13.7 & 0.01 & 84.2 & 0.06 \\
\hline Puttlam & 6.4 & 1127 & 1.50 & 45.5 & 0.06 & 82.5 & 0.11 \\
\hline Anuradhapura & 17.4 & 2215 & 2.77 & 32.7 & 0.04 & 84.9 & 0.11 \\
\hline Polonnaruwa & 27.6 & 926 & 2.34 & 38.5 & 0.10 & 88 & 0.22 \\
\hline Badulla & 9.5 & 1877 & 2.21 & 77.2 & 0.09 & 89 & 0.10 \\
\hline Moneragala & 2.1 & 1023 & 2.41 & 43.8 & 0.10 & 78.8 & 0.19 \\
\hline Ratnapura & 13 & 1836 & 1.69 & 52.8 & 0.05 & 78.6 & 0.07 \\
\hline Kegalle & 7.5 & 1468 & 1.83 & 44.9 & 0.06 & 93.6 & 0.12 \\
\hline
\end{tabular}


Table 3: Summary Statistics for Full Sample

\begin{tabular}{|c|c|c|c|c|c|}
\hline Variable & Observations & Mean & $\begin{array}{r}\text { Standard } \\
\text { Deviation }\end{array}$ & Minimum & Maximum \\
\hline ELF Index & 130 & 0.322 & 0.199 & 0.001 & 0.694 \\
\hline Tamil \% & 130 & 19.13 & 30.28 & 0.3 & 99.95 \\
\hline Moor \% & 130 & 9.90 & 11.80 & 0.04 & 49.80 \\
\hline Indian Tamil \% & 125 & 7,93 & 12.97 & 0.00 & 59.20 \\
\hline $\begin{array}{l}\text { Political Fractionalisation } \\
\text { Index }\end{array}$ & 101 & 0.416 & 0.231 & 0.00 & 0.777 \\
\hline Ethnic Polarisation Index & 126 & 0.513 & 0.021 & 0.002 & 0.927 \\
\hline $\begin{array}{l}\text { Political Polarisation } \\
\text { Index }\end{array}$ & 101 & 0.708 & 0.343 & 0 & 1.00 \\
\hline $\begin{array}{l}\text { Government Schools } \\
\text { (number) }\end{array}$ & 104 & 393.89 & 215.81 & 74 & 1074 \\
\hline $\begin{array}{l}\text { Government School } \\
\text { Teachers (number) }\end{array}$ & 104 & 6208.14 & 4598.76 & 413 & 19,940 \\
\hline $\begin{array}{l}\text { Government Health } \\
\text { Medical Officers } \\
\text { (number) }\end{array}$ & 80 & 428.40 & 582.23 & 20 & 3145 \\
\hline $\begin{array}{l}\text { Maternal Deaths (per } \\
1000 \text { live births) }\end{array}$ & 118 & 0.88 & 0.85 & 0.03 & 3.70 \\
\hline $\begin{array}{l}\text { Infant Mortality (per } \\
1000 \text { live births) }\end{array}$ & 120 & 26.45 & 19.26 & 1.2 & 100 \\
\hline $\begin{array}{l}\text { Electricity (Availability } \\
\text { of electricity lines near } \\
\text { household) }\end{array}$ & 72 & 82.67 & 8.85 & 63 & 100 \\
\hline $\begin{array}{l}\text { Water (Availability of } \\
\text { water lines near } \\
\text { household) }\end{array}$ & 72 & 40.47 & 19.44 & 7 & 89.4 \\
\hline Road Kilometerage & 91 & 1104.69 & 527.09 & 267 & 2500 \\
\hline Population ('000) & 137 & 619.35 & 510.99 & 35.1 & 2672.3 \\
\hline $\begin{array}{l}\text { Mean Per Capita Income } \\
\text { (Rupees) }\end{array}$ & 68 & 3154.72 & 2113.57 & 800 & 10,165 \\
\hline Literacy Rate & 72 & 87.08 & 5.10 & 75 & 96.3 \\
\hline Gini Coefficient & 74 & 0.46 & 0.09 & 0.31 & 0.75 \\
\hline
\end{tabular}

Table 4: Correlation between the Fractionalisation and Polarisation Indices

\begin{tabular}{lrrrr}
\hline & ELF & POLFRAC & EPI & POLPI \\
\hline ELF & 1.00 & - & - & - \\
\hline POLFRAC & 0.107 & 1.00 & - & - \\
\hline EPI & 0.977 & 0.131 & 1.00 & - \\
\hline POLPI & 0.06 & 0.921 & 0.101 & 1.00 \\
\hline
\end{tabular}


Table 5: Pooled OLS

\begin{tabular}{|c|c|c|c|c|c|c|c|c|}
\hline & \multicolumn{8}{|c|}{ Dependent Variables } \\
\hline & $(1)$ & $(2)$ & (3) & $(4)$ & (5) & (6) & (7) & (8) \\
\hline Independent & Govt & Govt & Govt & Maternal & Infant & Electricit & Water & Road \\
\hline Variables & Schools & Teachers & $\begin{array}{l}\text { Health } \\
\text { Medical } \\
\text { Officers }\end{array}$ & Deaths & Mortality & $\begin{array}{l}\text { y } \\
\text { Availabil } \\
\text { ity }\end{array}$ & $\begin{array}{l}\text { Availabilit } \\
\text { y }\end{array}$ & $\begin{array}{l}\text { Kilomet } \\
\text { erage }\end{array}$ \\
\hline ELF & $\begin{array}{l}-0.001 \\
(0.021)\end{array}$ & $\begin{array}{l}-0.004 \\
(0.001)^{*} \\
* *\end{array}$ & $\begin{array}{l}-0.004 \\
(0.102)\end{array}$ & $\begin{array}{c}0.004 \\
(0.005)\end{array}$ & $\begin{array}{l}0.002 \\
(0.006)\end{array}$ & $\begin{array}{l}-0.005 \\
(0.002)^{*} \\
*\end{array}$ & $\begin{array}{l}-0.004 \\
(0.002)^{*}\end{array}$ & $\begin{array}{l}-0.007 \\
(0.005)\end{array}$ \\
\hline POLFRAC & $\begin{array}{l}-0.013 \\
(0.007)^{*}\end{array}$ & $\begin{array}{l}-0.006 \\
(0.002)^{*} \\
* *\end{array}$ & $\begin{array}{l}-0.008 \\
(0.003)^{*} \\
*\end{array}$ & $\begin{array}{c}0.007 \\
(0.009)\end{array}$ & $\begin{array}{l}0.004 \\
(0.002 * *\end{array}$ & $\begin{array}{l}-0.008 \\
(0.001)^{*} \\
*\end{array}$ & $\begin{array}{l}-0.007 \\
(0.004)^{*}\end{array}$ & $\begin{array}{l}-0.008 \\
(0.009)\end{array}$ \\
\hline ELF*POLFRAC & $\begin{array}{l}-0.011 \\
(0.005)^{*}\end{array}$ & $\begin{array}{l}-0.040 \\
(0.023)^{*}\end{array}$ & $\begin{array}{l}-0.007 \\
(0.002)^{*} \\
* *\end{array}$ & $\begin{array}{c}0.020 \\
(0.013)\end{array}$ & $\begin{array}{l}0.026 \\
(0.013)^{*} \\
*\end{array}$ & $\begin{array}{l}-0.036 \\
(0.018)^{*}\end{array}$ & $\begin{array}{l}-0.021 \\
(0.013) *\end{array}$ & $\begin{array}{l}-0.048 \\
(0.023) \\
* *\end{array}$ \\
\hline population & $\begin{array}{l}0.027 \\
(0.011)^{*} \\
* *\end{array}$ & $\begin{array}{l}0.104 \\
(0.012)^{*} \\
* *\end{array}$ & $\begin{array}{l}0.049 \\
(0.021)^{*} \\
*\end{array}$ & $\begin{array}{l}0.079 \\
(0.050)\end{array}$ & $\begin{array}{l}0.040 \\
(0.034)\end{array}$ & $\begin{array}{l}0.029 \\
(0.038)\end{array}$ & $\begin{array}{l}-0.031 \\
(0.424)\end{array}$ & $\begin{array}{l}0.038 \\
(0.010) \\
* * *\end{array}$ \\
\hline Literacy Rate & $\begin{array}{l}0.015 \\
(0.011)\end{array}$ & $\begin{array}{l}0.019 \\
(0.011)^{*}\end{array}$ & $\begin{array}{l}0.033 \\
(0.017)^{*} \\
*\end{array}$ & $\begin{array}{l}-0.045 \\
(0.021)\end{array}$ & $\begin{array}{l}-0.032 \\
(0.110)\end{array}$ & $\begin{array}{l}0.091 \\
(0.093)\end{array}$ & $\begin{array}{c}0.031 \\
(0.039)\end{array}$ & $\begin{array}{l}0.082 \\
(0.131)\end{array}$ \\
\hline Gini Coefficient & $\begin{array}{l}-0.007 \\
(0.009)\end{array}$ & $\begin{array}{l}0.004 \\
(0.002)^{*} \\
* *\end{array}$ & $\begin{array}{l}0.006 \\
(0.002)^{*} \\
* *\end{array}$ & $\begin{array}{l}0.005 \\
(0.010)\end{array}$ & $\begin{array}{l}0.005 \\
(0.006)\end{array}$ & $\begin{array}{l}-0.006 \\
(0.002)^{*} \\
* *\end{array}$ & $\begin{array}{l}-0.006 \\
(0.018)\end{array}$ & $\begin{array}{l}0.007 \\
(0.005)\end{array}$ \\
\hline $\begin{array}{l}\text { Per Capita } \\
\text { Income }\end{array}$ & $\begin{array}{l}-0.017 \\
(0.003)^{*} \\
* *\end{array}$ & $\begin{array}{l}0.002 \\
(0.016)\end{array}$ & $\begin{array}{l}0.017 \\
(0.005)^{*} \\
* *\end{array}$ & $\begin{array}{l}-0.023 \\
(0.008) * \\
* *\end{array}$ & $\begin{array}{l}-0.002 \\
(0.001)^{*} \\
*\end{array}$ & $\begin{array}{l}0.012 \\
(0.004) * \\
* *\end{array}$ & $\begin{array}{l}-0.007 \\
(0.002)^{* *}\end{array}$ & $\begin{array}{l}-0.028 \\
(0.015) \\
* *\end{array}$ \\
\hline $\begin{array}{l}\text { Dummy for } \\
\text { North and East }\end{array}$ & $\begin{array}{l}-0.012 \\
(0.008) *\end{array}$ & $\begin{array}{l}-0.010 \\
(0.005)^{*} \\
*\end{array}$ & $\begin{array}{l}-0.009 \\
(0.005) *\end{array}$ & $\begin{array}{c}0.005 \\
(0.006)\end{array}$ & $\begin{array}{l}0.007 \\
(0.004)^{*}\end{array}$ & $\begin{array}{l}-0.010 \\
(0.006)^{*}\end{array}$ & $\begin{array}{l}-0.009 \\
(0.005)^{* *}\end{array}$ & $\begin{array}{l}-0.005 \\
(0.004)\end{array}$ \\
\hline $\mathrm{R}^{2}$ & 0.81 & 0.96 & 0.91 & 0.28 & 0.22 & 0.77 & 0.46 & 0.51 \\
\hline Observations & 60 & 60 & 60 & 60 & 60 & 60 & 60 & 60 \\
\hline
\end{tabular}

Note: Robust standard errors reported within parenthesis. *, **, ***, significant at the $10 \%, 5 \%$ and $1 \%$ levels respectively. 
Table 6: Pooled OLS Including Percentage of Race

\begin{tabular}{|c|c|c|c|c|c|c|c|c|}
\hline & \multicolumn{8}{|c|}{ Dependent Variables } \\
\hline & $(1)$ & $(2)$ & (3) & (4) & (5) & (6) & $(7)$ & $(8)$ \\
\hline Independent & Govt & Govt & Govt & Maternal & Infant & Electricity & Water & Road \\
\hline Variables & Schools & Teachers & $\begin{array}{l}\text { Health } \\
\text { Medical } \\
\text { Officers }\end{array}$ & Deaths & Mortality & $\begin{array}{l}\text { Availabilit } \\
\text { y }\end{array}$ & Availability & $\begin{array}{l}\text { Kilomet } \\
\text { erage }\end{array}$ \\
\hline Tamil & $\begin{array}{l}-0.190 \\
(0.078)^{* *} \\
*\end{array}$ & $\begin{array}{l}-0.057 \\
(0.113)\end{array}$ & $\begin{array}{l}0.337 \\
(0.302)\end{array}$ & $\begin{array}{l}-0.230 \\
(0.104)^{* *}\end{array}$ & $\begin{array}{l}-0.219 \\
(0.399)\end{array}$ & $\begin{array}{l}-0.051 \\
(0.014)^{* *} \\
*\end{array}$ & $\begin{array}{l}0.296 \\
(0.242)\end{array}$ & $\begin{array}{l}-0.214 \\
(0.118) *\end{array}$ \\
\hline Indian Tamil & $\begin{array}{l}-0.025 \\
(0.035)\end{array}$ & $\begin{array}{l}-0.029 \\
(0.016) *\end{array}$ & $\begin{array}{l}-0.203 \\
(0.100)^{*}\end{array}$ & $\begin{array}{l}-0.010 \\
(0.058)\end{array}$ & $\begin{array}{l}-0.130 \\
(0.156)\end{array}$ & $\begin{array}{l}-0.041 \\
(0.010)^{* *} \\
*\end{array}$ & $\begin{array}{l}-0.181 \\
(0.100)^{*}\end{array}$ & $\begin{array}{l}-0.170 \\
(0.091)^{*}\end{array}$ \\
\hline Moor & $\begin{array}{l}-0.050 \\
(0.072)\end{array}$ & $\begin{array}{l}0.099 \\
(0.081)\end{array}$ & $\begin{array}{l}-0.564 \\
(0.272)^{* *}\end{array}$ & $\begin{array}{l}-0.123 \\
(0.025)^{* *} \\
*\end{array}$ & $\begin{array}{l}-0.074 \\
(0.366)\end{array}$ & $\begin{array}{l}-0.080 \\
(0.039)^{* *}\end{array}$ & $\begin{array}{l}-0.039 \\
(0.422)\end{array}$ & $\begin{array}{l}-0.249 \\
(0.384)\end{array}$ \\
\hline ELF & $\begin{array}{l}-0.004 \\
(0.002)^{* *}\end{array}$ & $\begin{array}{l}-0.002 \\
(0.001)^{*}\end{array}$ & $\begin{array}{l}-0.002 \\
(0.001)^{*}\end{array}$ & $\begin{array}{l}0.023 \\
(0.042)\end{array}$ & $\begin{array}{l}0.022 \\
(0.012) \\
\end{array}$ & $\begin{array}{l}-0.012 \\
(0.006)^{* *}\end{array}$ & $\begin{array}{l}-0.004 \\
(0.002)^{*}\end{array}$ & $\begin{array}{l}-0.003 \\
(0.004) \\
\end{array}$ \\
\hline POLFRAC & $\begin{array}{l}-0.004 \\
(0.004)^{*}\end{array}$ & $\begin{array}{l}-0.008 \\
(0.002)^{* *} \\
*\end{array}$ & $\begin{array}{l}-0.006 \\
(0.003) * *\end{array}$ & $\begin{array}{c}0.002 \\
(0.002)\end{array}$ & $\begin{array}{l}0.002 \\
(0.001)^{*}\end{array}$ & $\begin{array}{l}-0.004 \\
(0.002)^{* *}\end{array}$ & $\begin{array}{l}0.004 \\
(0.002)^{* *}\end{array}$ & $\begin{array}{l}-0.001 \\
(0.101)\end{array}$ \\
\hline ELF*POLFRAC & $\begin{array}{l}-0.006 \\
(0.003)^{* *}\end{array}$ & $\begin{array}{l}-0.008 \\
(0.004)^{* *}\end{array}$ & $\begin{array}{l}-0.006 \\
(0.003)^{*}\end{array}$ & $\begin{array}{l}-0.008 \\
(0.003)^{* *} \\
*\end{array}$ & $\begin{array}{l}-0.004 \\
(0.002)^{* *}\end{array}$ & $\begin{array}{l}0.006 \\
(0.003)^{*}\end{array}$ & $\begin{array}{l}0.008 \\
(0.004)^{*}\end{array}$ & $\begin{array}{l}-0.003 \\
(0.003)\end{array}$ \\
\hline population & $\begin{array}{l}0.042 \\
(0.014)^{* *} \\
*\end{array}$ & $\begin{array}{l}0.107 \\
(0.015)^{* *} \\
*\end{array}$ & $\begin{array}{l}0.116 \\
(0.033)^{* *} \\
*\end{array}$ & $\begin{array}{l}0.083 \\
(0.023)^{* *} \\
*\end{array}$ & $\begin{array}{l}0.146 \\
(0.144)\end{array}$ & $\begin{array}{l}0.058 \\
(0.035)^{*}\end{array}$ & $\begin{array}{l}-0.108 \\
(0.197)\end{array}$ & $\begin{array}{l}0.034 \\
(0.018) *\end{array}$ \\
\hline Literacy Rate & $\begin{array}{c}0.325 \\
(0.190)^{*}\end{array}$ & $\begin{array}{l}0.265 \\
(0.111)^{* *} \\
*\end{array}$ & $\begin{array}{l}0.217 \\
(0.144)^{*}\end{array}$ & $\begin{array}{l}-0.150 \\
(0.006)^{* *}\end{array}$ & $\begin{array}{l}-0.265 \\
(0.513)\end{array}$ & $\begin{array}{l}0.194 \\
(0.166)\end{array}$ & $\begin{array}{l}0.295 \\
(0.542)\end{array}$ & $\begin{array}{c}0.021 \\
(0.414)\end{array}$ \\
\hline Gini Coefficient & $\begin{array}{l}0.008 \\
(0.004)^{*}\end{array}$ & $\begin{array}{l}0.004 \\
(0.001)^{* *} \\
*\end{array}$ & $\begin{array}{l}-0.003 \\
(0.006)\end{array}$ & $\begin{array}{l}0.004 \\
(0.002) *\end{array}$ & $\begin{array}{l}0.004 \\
(0.004)\end{array}$ & $\begin{array}{l}-0.007 \\
(0.002)^{* *} \\
*\end{array}$ & $\begin{array}{l}-0.003 \\
(0.004)\end{array}$ & $\begin{array}{l}0.009 \\
(0.009)\end{array}$ \\
\hline Per Capita Income & $\begin{array}{l}-0.128 \\
(0.050)^{* *} \\
*\end{array}$ & $\begin{array}{l}0.120 \\
(0.060)^{* *}\end{array}$ & $\begin{array}{l}0.154 \\
(0.039) * * \\
*\end{array}$ & $\begin{array}{l}-0.199 \\
(0.140)\end{array}$ & $\begin{array}{l}-0.092 \\
(0.043)^{* *}\end{array}$ & $\begin{array}{l}0.069 \\
(0.024)^{* *} \\
*\end{array}$ & $\begin{array}{l}-0.098 \\
(0.055)^{*}\end{array}$ & $\begin{array}{l}-0.164 \\
(0.054)^{*} \\
* *\end{array}$ \\
\hline $\begin{array}{l}\text { Dummy for North } \\
\text { and East }\end{array}$ & $\begin{array}{l}-0.013 \\
(0.007)^{* *}\end{array}$ & $\begin{array}{l}-0.010 \\
(0.006)^{*}\end{array}$ & $\begin{array}{l}-0.010 \\
(0.008)\end{array}$ & $\begin{array}{c}0.005 \\
(0.006)\end{array}$ & $\begin{array}{l}0.008 \\
(0.004)^{* *}\end{array}$ & $\begin{array}{l}-0.011 \\
(0.006)^{*}\end{array}$ & $\begin{array}{l}-0.008 \\
(0.005)^{*}\end{array}$ & $\begin{array}{l}-0.005 \\
(0.005) \\
\end{array}$ \\
\hline $\mathrm{R}^{2}$ & 0.80 & 0.91 & 0.90 & 0.51 & 0.33 & 0.85 & 0.70 & 0.80 \\
\hline Observations & 60 & 60 & 60 & 60 & 60 & 60 & 60 & 60 \\
\hline
\end{tabular}

Note: Robust standard errors reported within parenthesis. *, **, ***, significant at the $10 \%, 5 \%$ and $1 \%$ levels respectively. 
Table 7: Testing for Non-linear Effects

\begin{tabular}{|c|c|c|c|c|c|c|c|c|}
\hline & \multicolumn{8}{|c|}{ Dependent Variables } \\
\hline & $(1)$ & $(2)$ & (3) & $(4)$ & (5) & $(6)$ & $(7)$ & $(8)$ \\
\hline Independent & Govt & Govt & Govt & Maternal & Infant & Electricit & Water & Road \\
\hline Variables & Schools & Teachers & $\begin{array}{l}\text { Health } \\
\text { Medical } \\
\text { Officers }\end{array}$ & Deaths & Mortality & $\begin{array}{l}\text { y } \\
\text { Availabil } \\
\text { ity }\end{array}$ & $\begin{array}{l}\text { Availabilit } \\
\mathrm{y}\end{array}$ & $\begin{array}{l}\text { Kilomet } \\
\text { erage }\end{array}$ \\
\hline ELF & $\begin{array}{l}-0.002 \\
(0.003)\end{array}$ & $\begin{array}{l}-0.006 \\
(0.003)^{*} \\
*\end{array}$ & $\begin{array}{l}-0.001 \\
(0.002)\end{array}$ & $\begin{array}{c}0.002 \\
(0.004)\end{array}$ & $\begin{array}{l}0.005 \\
(0.004)\end{array}$ & $\begin{array}{l}-0.004 \\
(0.002)^{*}\end{array}$ & $\begin{array}{l}-0.006 \\
(0.002)^{* * *}\end{array}$ & $\begin{array}{l}-0.004 \\
(0.004)\end{array}$ \\
\hline POLFRAC & $\begin{array}{l}-0.005 \\
(0.002)^{*} \\
*\end{array}$ & $\begin{array}{l}-0.006 \\
(0.003) *\end{array}$ & $\begin{array}{l}-0.007 \\
(0.002)^{* * *}\end{array}$ & $\begin{array}{c}0.001 \\
(0.001)\end{array}$ & $\begin{array}{l}0.006 \\
(0.002)^{* * *}\end{array}$ & $\begin{array}{l}-0.002 \\
(0.001)^{*}\end{array}$ & $\begin{array}{l}-0.006 \\
(0.002)^{* * *}\end{array}$ & $\begin{array}{l}0.002 \\
(0.003)\end{array}$ \\
\hline $\mathrm{ELF}^{2}$ & $\begin{array}{l}0.002 \\
(0.003)\end{array}$ & $\begin{array}{l}0.002 \\
(0.002)\end{array}$ & $\begin{array}{l}0.002 \\
(0.001)^{*}\end{array}$ & $\begin{array}{r}-0.003 \\
(0.002)\end{array}$ & $\begin{array}{l}-0.001 \\
(0.001)\end{array}$ & $\begin{array}{l}0.003 \\
(0.004)\end{array}$ & $\begin{array}{l}0.001 \\
(0.001)\end{array}$ & $\begin{array}{l}0.002 \\
(0.0038 \\
)\end{array}$ \\
\hline $\mathrm{R}^{2}$ & 0.06 & 0.09 & 0.10 & 0.05 & 0.07 & 0.08 & 0.05 & 0.06 \\
\hline Observations & 65 & 65 & 67 & 73 & 73 & 61 & 61 & 66 \\
\hline
\end{tabular}

Note: Robust standard errors reported within parenthesis. *, **, ***, significant at the $10 \%, 5 \%$ and $1 \%$ levels respectively. 
Table 8: Using the Polarization Indices

\begin{tabular}{|c|c|c|c|c|c|c|c|c|}
\hline & \multicolumn{8}{|c|}{ Dependent Variables } \\
\hline & $(1)$ & $(2)$ & (3) & $(4)$ & $(5)$ & (6) & (7) & (8) \\
\hline Independent & Govt & Govt & Govt & Maternal & Infant & Electricit & Water & Road \\
\hline Variables & Schools & Teachers & $\begin{array}{l}\text { Health } \\
\text { Medical } \\
\text { Officers }\end{array}$ & Deaths & Mortality & $\begin{array}{l}\text { y } \\
\text { Availabil } \\
\text { ity }\end{array}$ & $\begin{array}{l}\text { Availabilit } \\
\text { y }\end{array}$ & $\begin{array}{l}\text { Kilomet } \\
\text { erage }\end{array}$ \\
\hline PI & $\begin{array}{l}-0.006 \\
(0.003)^{*} \\
*\end{array}$ & $\begin{array}{l}-0.001 \\
(0.001)\end{array}$ & $\begin{array}{l}-0.004 \\
(0.002)^{*} \\
*\end{array}$ & $\begin{array}{c}0.004 \\
(0.004)\end{array}$ & $\begin{array}{l}0.002 \\
(0.002)\end{array}$ & $\begin{array}{l}-0.002 \\
(0.002)\end{array}$ & $\begin{array}{l}-0.001 \\
(0.001)\end{array}$ & $\begin{array}{l}-0.003 \\
(0.005)\end{array}$ \\
\hline POLPI & $\begin{array}{l}-0.010 \\
(0.005)^{*} \\
*\end{array}$ & $\begin{array}{l}-0.004 \\
(0.002)^{*} \\
*\end{array}$ & $\begin{array}{l}-0.006 \\
(0.003)^{*} \\
*\end{array}$ & $\begin{array}{c}0.005 \\
(0.006)\end{array}$ & $\begin{array}{l}0.005 \\
(0.002)^{*} \\
*\end{array}$ & $\begin{array}{l}-0.004 \\
(0.001)^{*} \\
* *\end{array}$ & $\begin{array}{l}-0.006 \\
(0.003)^{*}\end{array}$ & $\begin{array}{l}-0.006 \\
(0.005)\end{array}$ \\
\hline PI*POLPI & $\begin{array}{l}-0.010 \\
(0.005)^{*}\end{array}$ & $\begin{array}{l}-0.010 \\
(0.005)^{*}\end{array}$ & $\begin{array}{l}-0.006 \\
(0.002)^{*} \\
* *\end{array}$ & $\begin{array}{c}0.008 \\
(0.010)\end{array}$ & $\begin{array}{l}0.006 \\
(0.003)^{*} \\
*\end{array}$ & $\begin{array}{l}-0.007 \\
(0.003)^{*} \\
*\end{array}$ & $\begin{array}{l}-0.006 \\
(0.003) *\end{array}$ & $\begin{array}{l}-0.005 \\
(0.002) \\
* *\end{array}$ \\
\hline population & $\begin{array}{l}0.005 \\
(0.002)^{*} \\
* *\end{array}$ & $\begin{array}{l}0.031 \\
(0.010)^{*} \\
* *\end{array}$ & $\begin{array}{l}0.021 \\
(0.010) * \\
*\end{array}$ & $\begin{array}{l}0.013 \\
(0.006)^{*} \\
*\end{array}$ & $\begin{array}{l}0.040 \\
(0.034)\end{array}$ & $\begin{array}{l}-0.020 \\
(0.011)^{*} \\
*\end{array}$ & $\begin{array}{l}-0.023 \\
(0.024)\end{array}$ & $\begin{array}{l}0.016 \\
(0.010) \\
*\end{array}$ \\
\hline Literacy Rate & $\begin{array}{l}0.014 \\
(0.010)\end{array}$ & $\begin{array}{l}0.020 \\
(0.010)^{*}\end{array}$ & $\begin{array}{l}0.021 \\
(0.007) * \\
* *\end{array}$ & $\begin{array}{l}-0.015 \\
(0.007) *\end{array}$ & $\begin{array}{l}-0.024 \\
(0.012)^{*} \\
*\end{array}$ & $\begin{array}{l}0.045 \\
(0.043)\end{array}$ & $\begin{array}{c}0.020 \\
(0.019)\end{array}$ & $\begin{array}{l}0.032 \\
(0.031)\end{array}$ \\
\hline Gini Coefficient & $\begin{array}{l}-0.021 \\
(0.021)\end{array}$ & $\begin{array}{l}0.027 \\
(0.012)^{*} \\
*\end{array}$ & $\begin{array}{l}0.031 \\
(0.015) * \\
*\end{array}$ & $\begin{array}{l}0.054 \\
(0.010)^{*} \\
* *\end{array}$ & $\begin{array}{l}0.035 \\
(0.016)^{*} \\
*\end{array}$ & $\begin{array}{l}-0.006 \\
(0.005)\end{array}$ & $\begin{array}{l}-0.004 \\
(0.007)\end{array}$ & $\begin{array}{l}0.021 \\
(0.025)\end{array}$ \\
\hline $\begin{array}{l}\text { Per Capita } \\
\text { Income }\end{array}$ & $\begin{array}{l}-0.012 \\
(0.004)^{*} \\
* *\end{array}$ & $\begin{array}{l}0.010 \\
(0.005)^{*} \\
*\end{array}$ & $\begin{array}{l}0.014 \\
(0.007)^{*} \\
*\end{array}$ & $\begin{array}{l}-0.020 \\
(0.008)^{*} \\
* *\end{array}$ & $\begin{array}{l}-0.003 \\
(0.001)^{*} \\
*\end{array}$ & $\begin{array}{l}0.009 \\
(0.004)^{*} \\
* *\end{array}$ & $\begin{array}{l}-0.008 \\
(0.002)^{* *}\end{array}$ & $\begin{array}{l}-0.013 \\
(0.007) \\
* *\end{array}$ \\
\hline $\begin{array}{l}\text { Dummy for } \\
\text { North and East }\end{array}$ & $\begin{array}{l}-0.007 \\
(0.003)^{*} \\
* *\end{array}$ & $\begin{array}{l}-0.005 \\
(0.002)^{*} \\
*\end{array}$ & $\begin{array}{l}-0.008 \\
(0.004)^{*}\end{array}$ & $\begin{array}{c}0.003 \\
(0.003)\end{array}$ & $\begin{array}{l}0.003 \\
(0.004)\end{array}$ & $\begin{array}{l}-0.011 \\
(0.005) * \\
*\end{array}$ & $\begin{array}{l}-0.010 \\
(0.005)^{* *}\end{array}$ & $\begin{array}{l}-0.004 \\
(0.004)\end{array}$ \\
\hline $\mathrm{R}^{2}$ & 0.78 & 0.77 & 0.75 & 0.65 & 0.68 & 0.66 & 0.56 & 0.59 \\
\hline Observations & 60 & 60 & 60 & 60 & 60 & 60 & 60 & 60 \\
\hline
\end{tabular}

Note: Robust standard errors reported within parenthesis. *, **, ***, significant at the $10 \%, 5 \%$ and $1 \%$ levels respectively. 
Table 9: Panel Fixed Effects Estimation with Additional Control Variables

\begin{tabular}{|c|c|c|c|c|c|c|c|c|}
\hline & \multicolumn{8}{|c|}{ Dependent Variables } \\
\hline & (1) & $(2)$ & (3) & $(4)$ & (5) & (6) & (7) & (8) \\
\hline Independent & Govt & Govt & Govt & Maternal & Infant & Electricit & Water & Road \\
\hline Variables & Schools & Teachers & $\begin{array}{l}\text { Health } \\
\text { Medical } \\
\text { Officers }\end{array}$ & Deaths & Mortality & $\begin{array}{l}\text { y } \\
\text { Availabil } \\
\text { ity }\end{array}$ & $\begin{array}{l}\text { Availabilit } \\
\text { y }\end{array}$ & $\begin{array}{l}\text { Kilomet } \\
\text { erage }\end{array}$ \\
\hline ELF & $\begin{array}{l}-0.009 \\
(0.002)^{*} \\
* *\end{array}$ & $\begin{array}{l}-0.003 \\
(0.001)^{*} \\
* *\end{array}$ & $\begin{array}{l}-0.005 \\
(0.004)\end{array}$ & $\begin{array}{c}0.001 \\
(0.001)\end{array}$ & $\begin{array}{l}0.004 \\
(0.002)^{*} \\
*\end{array}$ & $\begin{array}{l}-0.007 \\
(0.002)^{*} \\
* *\end{array}$ & $\begin{array}{l}-0.005 \\
(0.003)^{*}\end{array}$ & $\begin{array}{l}-0.004 \\
(0.002) \\
* *\end{array}$ \\
\hline POLFRAC & $\begin{array}{l}-0.010 \\
(0.004)^{*} \\
* *\end{array}$ & $\begin{array}{l}-0.004 \\
(0.002) * \\
*\end{array}$ & $\begin{array}{l}-0.004 \\
(0.002)^{*}\end{array}$ & $\begin{array}{c}0.004 \\
(0.003)\end{array}$ & $\begin{array}{l}0.005 \\
(0.002)^{*} \\
*\end{array}$ & $\begin{array}{l}-0.004 \\
(0.002)^{*}\end{array}$ & $\begin{array}{l}-0.004 \\
(0.002)^{*}\end{array}$ & $\begin{array}{l}-0.001 \\
(0.003)\end{array}$ \\
\hline ELF*POLFRAC & $\begin{array}{c}-0.006 \\
(0.003)^{*}\end{array}$ & $\begin{array}{c}-0.005 \\
(0.002)^{*}\end{array}$ & $\begin{array}{l}-0.006 \\
(0.002) * \\
*\end{array}$ & $\begin{array}{c}0.005 \\
(0.004)\end{array}$ & $\begin{array}{l}0.006 \\
(0.003)^{*}\end{array}$ & $\begin{array}{l}-0.008 \\
(0.002)^{*} \\
* *\end{array}$ & $\begin{array}{l}-0.004 \\
(0.002)^{*}\end{array}$ & $\begin{array}{c}0.003 \\
(0.004)\end{array}$ \\
\hline population & $\begin{array}{l}0.010 \\
(0.005) * \\
*\end{array}$ & $\begin{array}{l}0.014 \\
(0.005) * \\
* *\end{array}$ & $\begin{array}{l}0.011 \\
(0.003) * \\
*\end{array}$ & $\begin{array}{c}0.014 \\
(0.012)\end{array}$ & $\begin{array}{l}0.026 \\
(0.010) * \\
* *\end{array}$ & $\begin{array}{l}0.013 \\
(0.007) * \\
* *\end{array}$ & $\begin{array}{c}0.013 \\
(0.016)\end{array}$ & $\begin{array}{l}0.026 \\
(0.024)\end{array}$ \\
\hline Literacy Rate & $\begin{array}{c}0.019 \\
(0.130)\end{array}$ & $\begin{array}{l}0.027 \\
(0.009)^{*} \\
* *\end{array}$ & $\begin{array}{l}0.010 \\
(0.005) * \\
*\end{array}$ & $\begin{array}{r}-0.188 \\
(0.106)\end{array}$ & $\begin{array}{l}-0.013 \\
(0.109)\end{array}$ & $\begin{array}{l}0.017 \\
(0.014)\end{array}$ & $\begin{array}{l}0.036 \\
(0.016)^{* *}\end{array}$ & $\begin{array}{l}0.029 \\
(0.009) \\
* * *\end{array}$ \\
\hline Gini Coefficient & $\begin{array}{c}-0.016 \\
(0.100)\end{array}$ & $\begin{array}{l}0.018 \\
(0.014)\end{array}$ & $\begin{array}{c}0.015 \\
(0.055)\end{array}$ & $\begin{array}{l}0.032 \\
(0.015)^{*} \\
*\end{array}$ & $\begin{array}{c}0.016 \\
(0.048)\end{array}$ & $\begin{array}{c}0.036 \\
(0.070)\end{array}$ & $\begin{array}{c}0.016 \\
(0.122)\end{array}$ & $\begin{array}{l}-0.003 \\
(0.050)\end{array}$ \\
\hline $\begin{array}{l}\text { Per Capita } \\
\text { Income }\end{array}$ & $\begin{array}{l}0.014 \\
(0.005)^{*} \\
* *\end{array}$ & $\begin{array}{l}0.012 \\
(0.004)^{*} \\
* *\end{array}$ & $\begin{array}{c}0.010 \\
(0.013)\end{array}$ & $\begin{array}{l}-0.018 \\
(0.007)^{*}\end{array}$ & $\begin{array}{l}-0.016 \\
(0.004)^{*} \\
* *\end{array}$ & $\begin{array}{l}0.010 \\
(0.005) * \\
*\end{array}$ & $\begin{array}{c}0.017 \\
(0.048)\end{array}$ & $\begin{array}{l}0.010 \\
(0.005) \\
* *\end{array}$ \\
\hline $\begin{array}{l}\text { Dummy for } \\
\text { North and East }\end{array}$ & $\begin{array}{l}-0.011 \\
(0.006) *\end{array}$ & $\begin{array}{l}-0.009 \\
(0.005)^{*}\end{array}$ & $\begin{array}{l}-0.008 \\
(0.007)\end{array}$ & $\begin{array}{l}-0.005 \\
(0.005)\end{array}$ & $\begin{array}{l}-0.006 \\
(0.004)^{*}\end{array}$ & $\begin{array}{l}-0.010 \\
(0.006)^{*}\end{array}$ & $\begin{array}{l}-0.008 \\
(0.005)^{*}\end{array}$ & $\begin{array}{l}-0.003 \\
(0.004)\end{array}$ \\
\hline $\mathrm{R}^{2}$ & 0.41 & 0.46 & 0.52 & 0.33 & 0.26 & 0.51 & 0.26 & 0.34 \\
\hline Observations & 60 & 60 & 60 & 60 & 60 & 60 & 60 & 60 \\
\hline
\end{tabular}

Note: Robust standard errors reported within parenthesis. *, **, ***, significant at the $10 \%, 5 \%$ and $1 \%$ levels respectively. 